\title{
Development of Cone Wedge Ring Expansion Test to Evaluate Mechanical Properties of Clad Tubing Structure
}

Jy-An John Wang Hao Jiang

October 6, 2016 


\section{DOCUMENT AVAILABILITY}

Reports produced after January 1, 1996, are generally available free via US Department of Energy (DOE) SciTech Connect.

\section{Website http://www.osti.gov/scitech/}

Reports produced before January 1, 1996, may be purchased by members of the public from the following source:

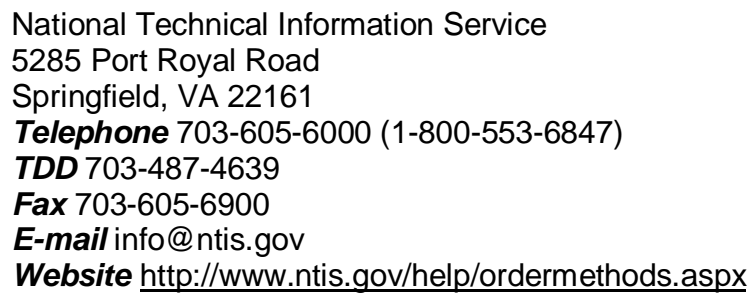

Reports are available to DOE employees, DOE contractors, Energy Technology Data Exchange representatives, and International Nuclear Information System representatives from the following source:

Office of Scientific and Technical Information

PO Box 62

Oak Ridge, TN 37831

Telephone 865-576-8401

Fax 865-576-5728

E-mail reports@osti.gov

Website http://www.osti.gov/contact.html

This report was prepared as an account of work sponsored by an agency of the United States Government. Neither the United States Government nor any agency thereof, nor any of their employees, makes any warranty, express or implied, or assumes any legal liability or responsibility for the accuracy, completeness, or usefulness of any information, apparatus, product, or process disclosed, or represents that its use would not infringe privately owned rights. Reference herein to any specific commercial product, process, or service by trade name, trademark, manufacturer, or otherwise, does not necessarily constitute or imply its endorsement, recommendation, or favoring by the United States Government or any agency thereof. The views and opinions of authors expressed herein do not necessarily state or reflect those of the United States Government or any agency thereof. 
Materials Science and Technology Division

Oak Ridge National Laboratory

\section{DEVELOPMENT OF CONE WEDGE RING EXPANSION TEST TO EVALUATE MECHANICAL PROPERTIES OF CLAD TUBING STRUCTURE}

Jy-An John Wang and Hao Jiang

Date Published: October 2016

Prepared by

OAK RIDGE NATIONAL LABORATORY

Oak Ridge, TN 37831-6283

managed by

UT-BATTELLE, LLC

for the

U.S. DEPARTMENT OF ENERGY

under contract DE-AC05-00OR22725 



\section{CONTENTS}

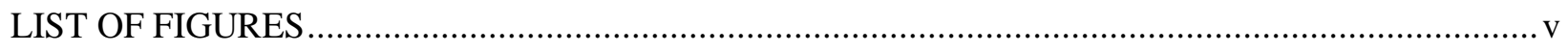

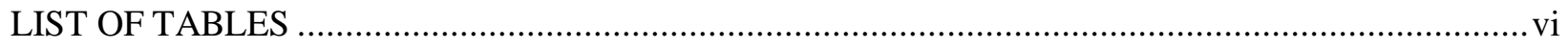

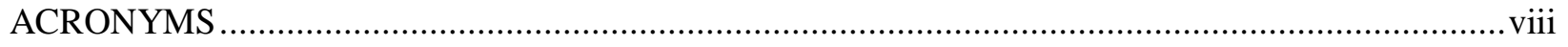

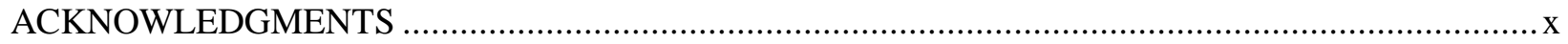

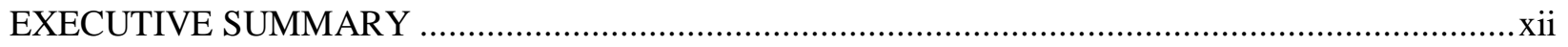

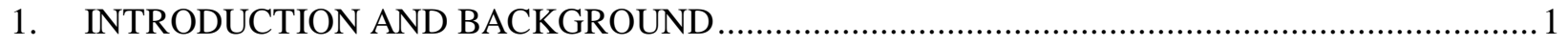

2. CONE WEDGE RING EXPANSION TEST METHOD DESIGN …....................................... 2

3. PILOT TEST FOR VERIFYING CONE WEDGE RING EXPANSION TEST DESIGN................ 8

4. TEST DATA CONVERTING TO HOOP STRESS-STRAIN CURVE …...................................15

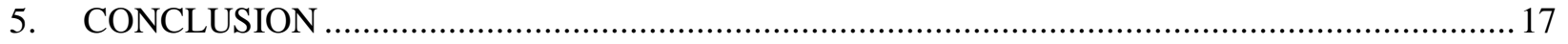

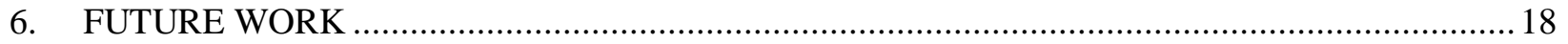

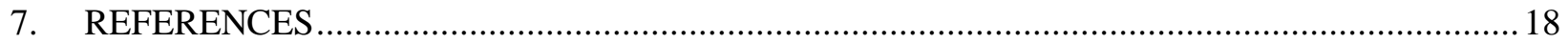





\section{LIST OF FIGURES}

Figure

Fig. 1 Hoop tensile techniques used to assess the mechanical property of fuel cladding [14].................... 1

Fig. 2. Cone wedge ring expansion test design with four-piece wedge inserts.................................... 3

Fig. 3. A uniaxial tensile tube test and tensile stress-strain curve for baseline $\mathrm{Zr}-4$ cladding. .................... 3

Fig. 4. Uniform stress distribution and uniform deformation in the clad for the cone wedge ring

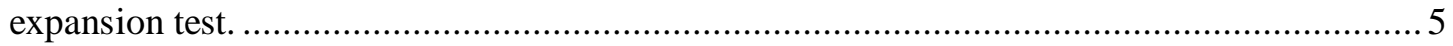

Fig. 5. Schematic for force transferring from loading piston to ring specimen .................................... 6

Fig. 6. FEA hoop stress-strain curves vs. tensile test data for the cone wedge ring expansion test method.

Fig. 7. Test setup for verifying cone wedge ring expansion test design. ............................................. 8

Fig. 8. Cone-shaped loading piston and a hole on the bottom support piston......................................... 9

Fig. 9. Untested Zr-4 ring specimens with the first two sets of the fabricated wedge inserts.................. 10

Fig. 10. Tested Zr-4 ring specimens using the first fabricated wedge inserts....................................... 11

Fig. 11. Test data for ring specimens tested with the first fabricated wedge inserts .............................. 12

Fig. 12. Untested Zr-4 ring specimen with the new fabricated wedge inserts. ...................................... 12

Fig. 13. Ring specimen with tapered wedge well matched with the cone-shaped piston......................... 13

Fig. 14. Tested Zr-4 ring specimens using the new wedge inserts. ................................................... 13

Fig. 15. Test data for ring specimens tested with the new wedge inserts. .......................................... 14

Fig. 16. Tested Zr-4 ring specimens using the new wedge inserts under different loading rates............... 14

Fig. 17. Test data for ring specimens tested with the new wedge inserts under different loading rates..... 15

Fig. 18. Load-extension data comparison between tests and FEA simulations with different friction

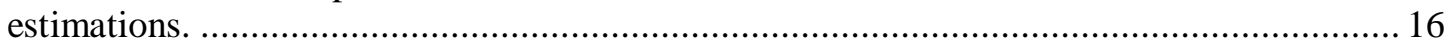

Fig. 19. Converted hoop stress-strain curves of ring test data compared with uniaxial tensile tube

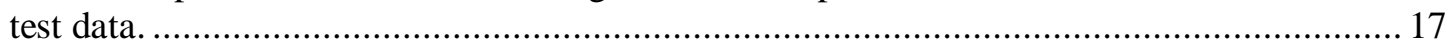




\section{LIST OF TABLES}

\section{Table}

Page

Table 1. Anisotropic mechanical properties of baseline Zircaloy at room temperature, from the

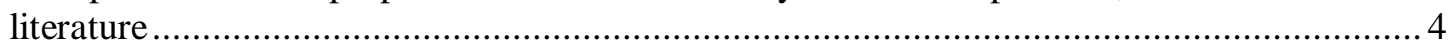

Table 2. FEA simulation using material properties of the expanded plug wedge test.............................. 5

Table 3.Friction coefficients at three interfaces and associated $\chi$ factor ............................................ 7 



\section{ACRONYMS}

$\begin{array}{ll}\text { BWR } & \text { boiling water reactor } \\ \text { EDC } & \text { expansion due to compression } \\ \text { FEA } & \text { finite element analysis } \\ \text { IAEA } & \text { International Atomic Energy Agency } \\ \text { ID } & \text { internal diameter } \\ \text { OD } & \text { outer diameter } \\ \text { ORNL } & \text { Oak Ridge National Laboratory } \\ \text { PNNL } & \text { Pacific Northwest National Laboratory } \\ \text { PWR } & \text { pressurized water reactor } \\ \text { RIA } & \text { reactivity-initiated accident }\end{array}$




\section{ACKNOWLEDGMENTS}

This research was sponsored by the Fuel Qualification Program of the US Department of Energy and was carried out at Oak Ridge National Laboratory under contract DE-AC05-00OR22725 with UT-Battelle, LLC.

The authors would like to thank program managers Bruce Bevard and Don Spellman for providing guidance and support to this project, Chris Stevens for performing the Zr-4 tensile test, and Randy Parton for machining and sample preparation. 



\section{EXECUTIVE SUMMARY}

To determine the hoop tensile properties of irradiated fuel cladding in a hot cell, a cone wedge ring expansion test method was developed. A four-piece wedge insert was designed with tapered angles matched to the cone shape of a loading piston. The ring specimen was expanded in the radial direction by the lateral expansion of the wedges under the downward movement of the piston. The advantages of the proposed method are that implementation of the test setup in a hot cell is simple and easy, and that it enables a direct strain measurement of the test specimen from the piston's vertical displacement soon after the wedge-clad contact resistance is initiated.

Finite element analysis (FEA) results show a uniform stress-strain profile at the gage section of the ring specimen under the cone wedge ring expansion test. A close-form solution was also developed to explicitly relate the hoop stress $\sigma_{\theta}$ to the piston loading using the $\chi$ factor. Applying the $\chi$ factor can accurately convert the applied piston load and the radial dilatation of the ring into hoop stress-strain curves. Literature data show the anisotropic material behavior of the baseline $\mathrm{Zr}-4$ cladding, and the differences between the axial and hoop stress range from $0 \%$ to $20 \%$.

Based on FEA simulations, the designed ring specimens and wedge inserts were fabricated for pilot testing validation. The geometries of the ring specimens in the pilot test were optimized through FEA. The wedges were machined to produce a tapered surface to fit the cone shape of the loading piston. With the newly developed wedge inserts, five $\mathrm{Zr}$-4 ring specimens were successfully tested to failure using the proposed cone wedge expansion test method. The ring specimens deformed uniformly in the axial and circumferential directions before a necking phenomenon occurred. The tested specimens at the target vertical piston displacement can achieve ring rupture failure through significant necking evolution. Furthermore, test results showed significant loading rate-dependent stress-strain profiles; thus, for hoop tensile strength evaluation under normal loading condition, a low loading rate is recommended.

With the associated friction coefficients at interfaces of test set-up estimated from FEA, the $\chi$ factor was determined accordingly. The developed close-form solution was then applied to extract the material hoop tensile properties of the fuel cladding from the measured load displacement in the cone wedge ring expansion testing protocol. The hoop tensile strength values using the proposed test method were about $10 \%$ higher than the clad axial tensile test values. The variation in the test results between the cone wedge ring expansion test and the uniaxial tensile tube test was within the range of the literature reported data.

Using the optimized test specimen and setup design, including the associated data processing procedure, the cone wedge ring expansion test protocol validated that the measured piston load, piston compression extension, and ring radial expansion can be effectively and accurately converted into a hoop tensile stressstrain curve for characterization of a clad tubing transverse material. The test method can also be extended for future high-temperature testing in hot cells. The pilot test also proved that the machining and testing for the cone wedge ring expansion test method were very robust. 


\section{INTRODUCTION AND BACKGROUND}

Various types of nuclear reactors-including the pressurized water reactors (PWRs) and boiling water reactors (BWRs) in the light water reactor fleet—use a zirconium alloy almost exclusively as a fuel cladding material because of its low neutron absorption, corrosion resistance, and outstanding mechanical performance under operating conditions. The most commonly used alloys are Zircaloy-2, Zircaloy-4, and more modern alloys such as M5. The zirconium-based alloy cladding is the first structural barrier for containing radioactive fission products, so its structural integrity and durability must be ensured throughout the fuel cycle. Numerous effects may degrade the mechanical performance of the cladding during operation, including high temperatures, hydrogen absorption, and oxidation. Thus, examination of its mechanical properties is essential to verify the fuel cladding performance.

Several research findings reveal that zirconium and its alloys have anisotropic material behavior [1-11]. Murty et al. [1-5] performed extensive studies of texture development and anisotropic material behavior in Zircaloys. Owing to the crystallographic texture of zirconium-based alloys, the mechanical strength and ductility vary between the transverse and longitudinal directions. When cladding tubes are extruded during the manufacturing process, this anisotropy is further enhanced. Daum et al. [12] conducted an axial tube specimen test and a plain strain ring stretch test to investigate the mechanical properties of Zircaloy-4 in the axial and circumferential directions. Their study suggests that the circumferential yield and flow stress are $\sim 10 \%$ higher than the axial yield and flow stress. Thus, it is necessary to determine the anisotropic mechanical behavior of cladding tubes in both the axial and transverse hoop directions.

As shown in Fig. 1, Desquines et al. [13] conducted a broad literature review of existing hoop tensile test techniques, focusing on cladding performance during a reactivity-initiated accident (RIA). The test procedures were performed on different specimen geometries using various loading configurations. Techniques such as the burst test were usually performed to study fracture behavior. Many techniques have evolved to determine the mechanical properties of cladding in the hoop direction.
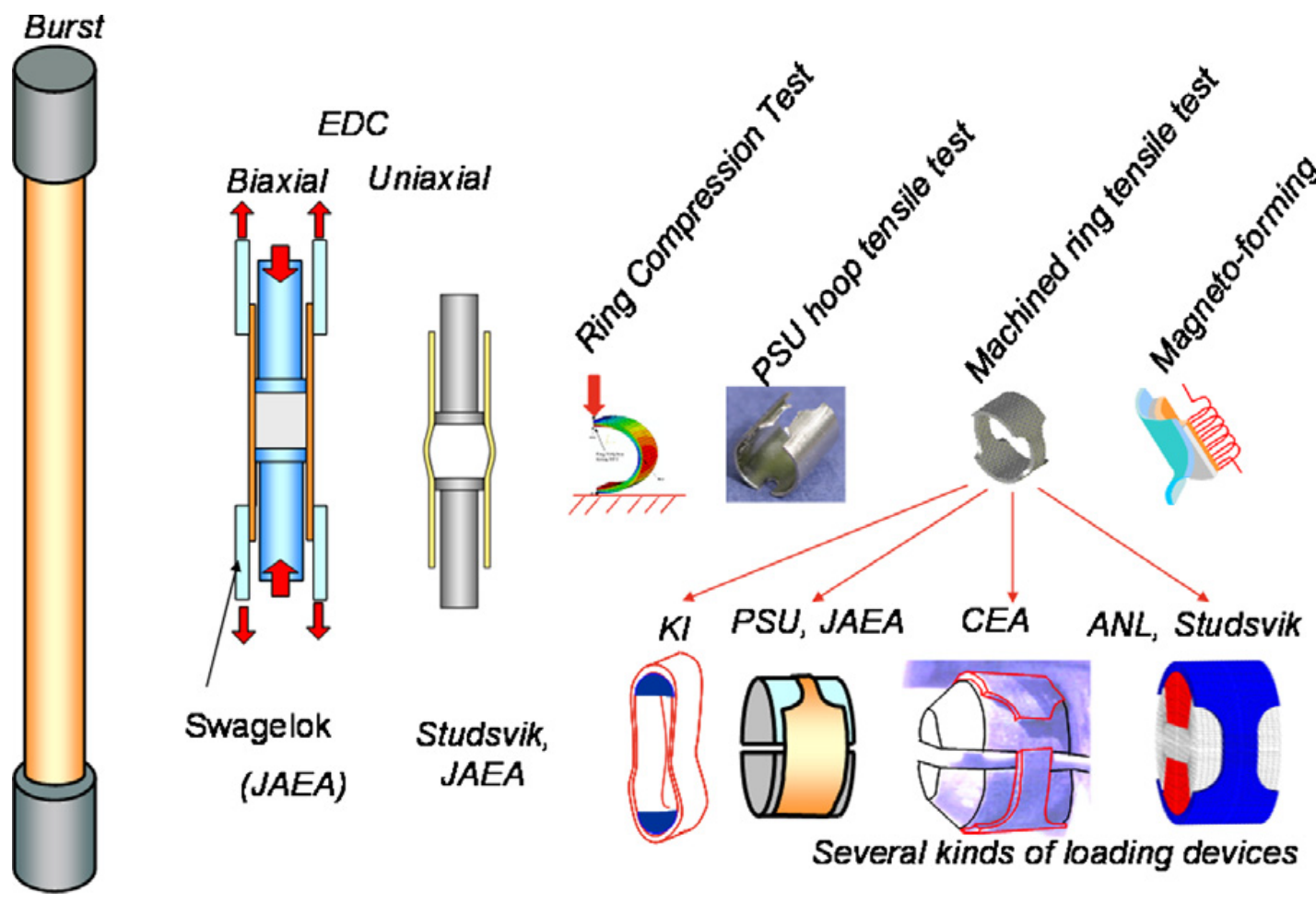

Fig. 1 Hoop tensile techniques used to assess the mechanical property of fuel cladding [14]. 
The burst test [14-20] provides the biaxial-stress evaluation of cladding yield and the deformation at small strains, where the test result is sensitive to the presence of defects. The ring tensile tests illustrated in Fig. 1 used several different specimen/grip configurations [20-34]. In all cases, the configurations of both grips and test specimens either imposed bending or introduced a friction component to the gage section of the specimen. As a result of bending, a nonuniform hoop stress distribution develops within the cladding. The frictional effect dictates a nonuniform strain distribution along a deforming section. The expansion due to compression (EDC) test depicted in Fig. 1, developed at Studsvik Nuclear and evaluated at Japan Atomic Energy Agency, offers a conveniently simple experimental solution [32-39]. However, owing to complex contact and several induced frictional effects, the EDC test is not well suited to deriving accurate yield strength or ultimate tensile strength values, as stated in Desquines et al. [13]. The ring compression test [40-43] assumes that compressive material properties are similar to those in tension. This is not the case if a crack initiates near the cladding outer surface as a hydride rim or if a blister is present. Moreover, the nature of the test makes it difficult to convert the test results for stressstrain behavior. The plane-strain tensile test [12, 20, 44-47] was designed at Pennsylvania State University. Desquines et al. [13] suggest that the test technique requires further development and testing to achieve a full understanding of results. The magneto-forming test [48-49] is a high-strain-rate forming procedure under development at Electricité de France. Although it is not well suited to determining the stress-strain response of the cladding tube, it may be useful for failure study.

Some other hoop tensile test methods not mentioned in the Desquines et al. [13] reviews include Nilsson et al. [50], in which the segmented expanding cone-mandrel test was developed to characterize materials for fuel cladding. Chu et al. [51] used a slotted arc tension specimen to obtain hoop mechanical properties. Hendrich et al. [52] invented an expanding plug test method, the deficiency of which has been stated in previous research [53].

To determine the hoop tensile properties of irradiated fuel cladding in a hot cell, a cone wedge ring expansion test method, based on a concept reported in Nilsson et al. [50], and an associated data processing procedure have been developed. The advantages of the proposed test method are the simple implementation in a hot cell and the direct strain measurement of the tested specimen through piston displacement. Finite element analysis (FEA) simulation indicates that the proposed approach results in a uniform stress-strain distribution at the gage section. A governing equation of the close-form solution was also developed to accurately covert the load displacement into the hoop tensile stress-strain curve of the tested cladding material using the $\chi$ factor.

The cone wedge ring expansion test method that was developed was also validated through pilot testing. The ring specimens and wedge inserts were fabricated based on an optimized FEA design. A loading piston was machined with a designed cone shape, and the wedge supporting piston was machined with a hole to allow the loading piston to pass through. The fabrication of wedge inserts was improved during several iterations of specimen preparation. The ring specimens were tested to fracture failure at the targeted piston displacement range.

\section{CONE WEDGE RING EXPANSION TEST METHOD DESIGN}

A schematic diagram of the designed cone wedge ring expansion test setup is shown in Fig. 2. In this FEA model, a loading piston was designed with a cone shape at a half angle of $13^{\circ}$, which enabled a $0.457 \mathrm{~mm}$ radial expansion of the wedge inserts under $2.032 \mathrm{~mm}$ of piston vertical movement. The four pieces of the wedge insert were designed with tapered angles to match the cone shape of the loading piston. The Zr-4 ring was expanded in the radial direction by the radial compression force transferred from the wedge insert. The wedges and ring could slide easily on the top surface of the supporting piston 
by overcoming the marginal friction force at the contact interfaces; these phenomena were further validated in an FEA simulation with a corresponding friction coefficient at interfaces.

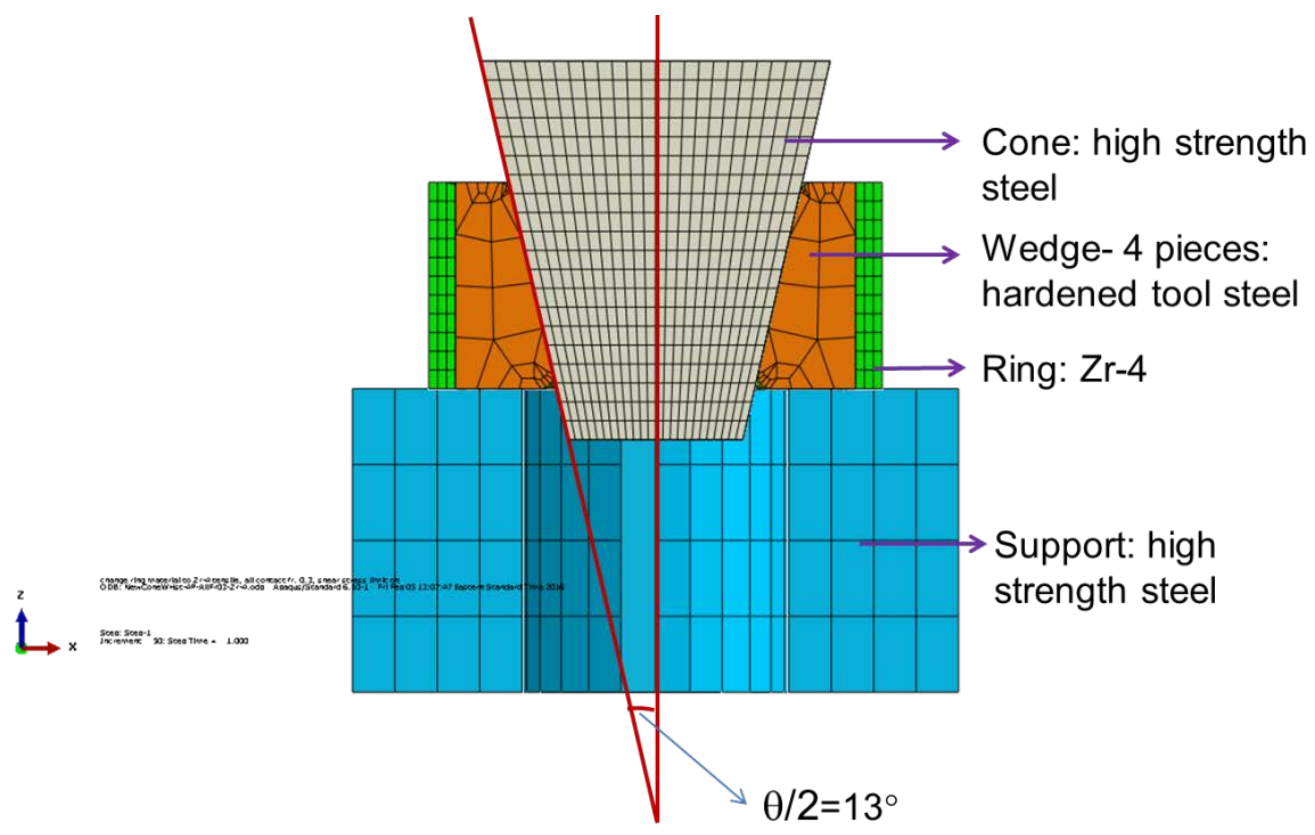

Fig. 2. Cone wedge ring expansion test design with four-piece wedge inserts.

A uniaxial tensile test was performed on baseline $\mathrm{Zr}$-4 cladding, the same material used in the ring specimen test. Figure 3 illustrates the tensile test and the measured stress-strain response from the test. The yield strength obtained from the tensile test of $152.4 \mathrm{~mm}$ baseline $\mathrm{Zr}-4$ cladding was $606 \mathrm{MPa}$, and the ultimate strength was up to $768 \mathrm{MPa}$.
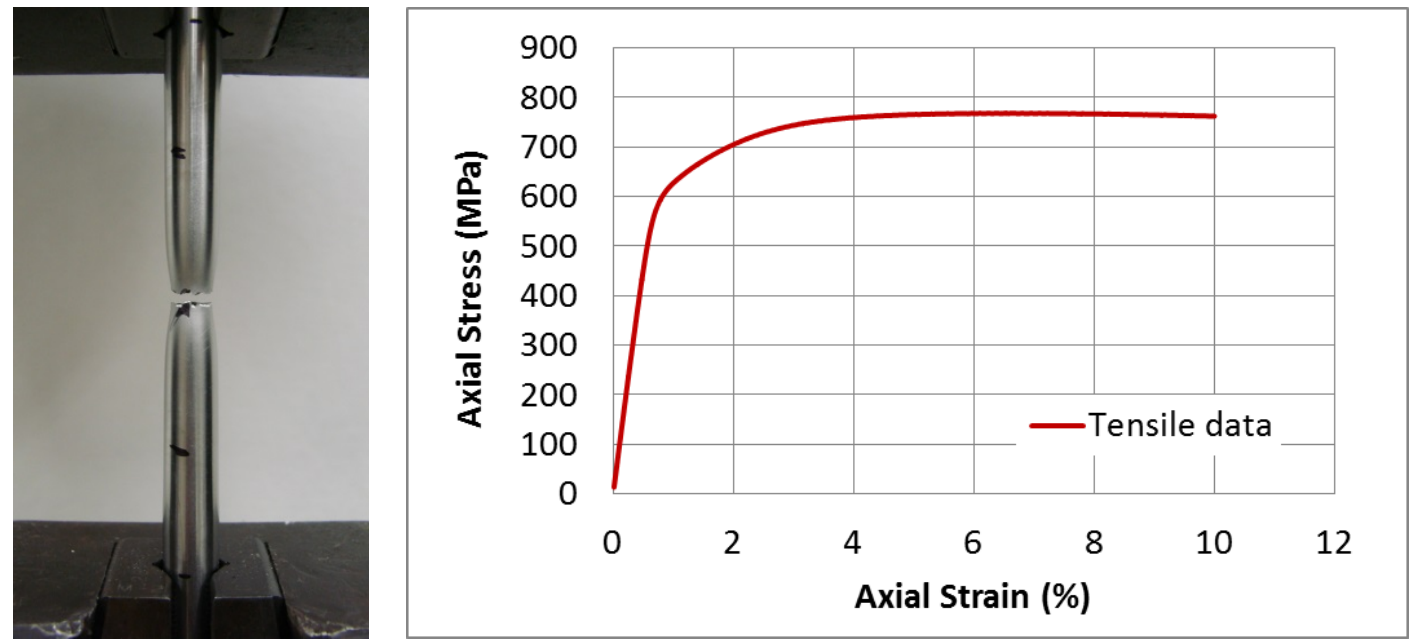

Fig. 3. A uniaxial tensile tube test and tensile stress-strain curve for baseline $\mathrm{Zr}-4$ cladding.

Table 1 summarizes the mechanical properties of unirradiated Zircaloy at room temperature based on the referenced literature. Compared to the literature data, yield strength and ultimate strength from our uniaxial tensile tube test are right in the range. Because the anisotropic material behavior of $\mathrm{Zr}-4$ depends on crystallite orientation, material treatment, manufacturing process, etc., the deviation of data from axial 
to hoop tensile varies. The difference also depends on test methods. In a Pacific Northwest National Laboratory (PNNL) report [56], the models of stress-strain correlation for Zircaloy were developed without consideration of anisotropic behavior. In this study, the $\mathrm{Zr}-4$ test tube is as received, and the history of the material treatment and manufacturing is unknown. To make a reasonable estimation from literature data, the yield and ultimate strength in the hoop direction is assumed to be $10 \%$ higher than the tensile tube test data; that is, the hoop tensile yield stress is estimated $667 \mathrm{MPa}$, and the hoop ultimate stress is estimated $845 \mathrm{MPa}$. The estimated hoop tensile data are also within the range of literature data.

Table 1. Anisotropic mechanical properties of baseline Zircaloy at room temperature, from the literature

\begin{tabular}{|c|c|c|c|c|c|c|}
\hline \multirow[t]{2}{*}{ References } & \multicolumn{2}{|c|}{ Axial tensile } & \multicolumn{2}{|c|}{ Hoop tensile } & \multicolumn{2}{|c|}{$\begin{array}{c}\text { Difference from } \\
\text { axial to hoop }\end{array}$} \\
\hline & $\begin{array}{l}\text { Yield } \\
\text { stress } \\
(\mathrm{MPa})\end{array}$ & $\begin{array}{l}\text { Ultimate } \\
\text { stress } \\
(\mathrm{MPa})\end{array}$ & $\begin{array}{l}\text { Yield stress } \\
\text { (MPa) }\end{array}$ & $\begin{array}{l}\text { Ultimate } \\
\text { stress } \\
(\mathrm{MPa})\end{array}$ & $\begin{array}{l}\text { Yield } \\
\text { stress }\end{array}$ & $\begin{array}{l}\text { Ultimate } \\
\text { stress }\end{array}$ \\
\hline Zr-2 BWR, impression test [1] & & 782 & & 804 & & $3 \%$ \\
\hline $\begin{array}{l}\mathrm{Zr-4} \text {, axial tube test, uniaxial } \\
\text { ring stretch test [12] }\end{array}$ & 578 & 706 & 638 & $>716$ & $10 \%$ & $\sim 10 \%$ \\
\hline $\begin{array}{l}\text { Zr-2 BWR, open-end burst test } \\
\text { [17] }\end{array}$ & & & 754 & 867 & & \\
\hline $\begin{array}{l}\text { Zr-4 PWR, AT, HT, internal } \\
\text { pressurization burst test [18] }\end{array}$ & 638 & & & 850 & $\begin{array}{l}20 \% \\
\text { from IP }\end{array}$ & \\
\hline $\begin{array}{l}\text { Zr-4, axial tensile, hoop tensile } \\
{[21,22]}\end{array}$ & 660 & 820 & & 840 & & $2 \%$ \\
\hline $\begin{array}{l}\text { Zr-4 Light water reactor, ring } \\
\text { tension test [23] }\end{array}$ & & & 600 & 760 & & \\
\hline Zr-4, hoop tensile test [24] & & & 660 & 830 & & \\
\hline Zr-4, ring tensile test [25] & & & 600 & 700 & & \\
\hline $\begin{array}{l}\text { Zr-4, uniaxial tension, slotted } \\
\text { arc tension [51] }\end{array}$ & 600 & 720 & 750 & 900 & $20 \%$ & $20 \%$ \\
\hline Zr-4, tensile test [54] & 600 & 780 & & & & \\
\hline Zr-4, tensile tube test [55] & 378 & 658 & & & & \\
\hline $\begin{array}{l}\text { Zr-4, predicted from Pacific } \\
\text { Northwest National } \\
\text { Laboratory model [56] }\end{array}$ & 578 & 715 & 578 & 715 & $0 \%$ & $0 \%$ \\
\hline $\begin{array}{l}\text { AREVA } \mathrm{Zr}-4^{*} \text {, tensile test, } \\
\text { burst test }\end{array}$ & 602 & 775 & & $\begin{array}{l}934 \text { (from } \\
\text { burst test) }\end{array}$ & & $20 \%$ \\
\hline
\end{tabular}

Unpublished data.

Estimated properties for the resulting responses are shown in Table 2. They include baseline $\mathrm{Zr}-4$ data for the clad ring material for the pilot testing. Strain-hardening data were generated on the basis of $10 \%$ higher tensile test data as shown in Fig. 3. These data were used as the input for the hoop plastic material behavior of $\mathrm{Zr}-4$ in the ring expansion FEA simulation. The material in the FEA model is the same as that used in the ring test. The material for the wedge insert was hardened tool steel, high-strength steel was used for the loading piston and supporting piston. Their properties were used in the FEA simulation and are listed in Table 2. 
Table 2. FEA simulation using material properties of the expanded plug wedge test

\begin{tabular}{lccc}
\hline Material (source) & $\begin{array}{c}\text { Young's modulus } \\
\text { (GPa) }\end{array}$ & $\begin{array}{c}\text { Tensile yield stress } \\
\text { (MPa) }\end{array}$ & Poisson's ratio \\
\hline Unirradiated Zr-4 $^{*}$ & 93.5 & 667 & 0.37 \\
High-strength steel $^{*}[57,58]$ & 206.8 & $1,930.5$ & 0.28 \\
Hardened tool steel $^{*}$ [59] & 204.8 & 689.5 & 0.285 \\
\hline
\end{tabular}

${ }^{*}$ Strain hardening data used in modeling.

Fig. 4 shows the uniform hoop stress and strain distribution in the clad along the circumferential orientation for the cone wedge ring expansion test. The clad was deformed uniformly in the radial direction and along the gage length. Note that a deformed ring is not perfectly round at the wedges opening sections. Nevertheless, if the circumferential lengths are calculated from real deformation and from simplified circle respectively, the difference between two circumferential length calculations is about $0.25 \%$ from ring final deformation at the target maximum wedge opening condition [60]. The gap deformation should be smaller at lower load, thus, the difference between the non-circular and perfect circle would be further reduced till the wedge opening gap close. The difference of circumferential length based on the above calculations varies from $0 \sim 0.25 \%$ during the ring deformation process. Therefore, the deformed ring was assigned as circle for further hoop strain calculation without losing generality.
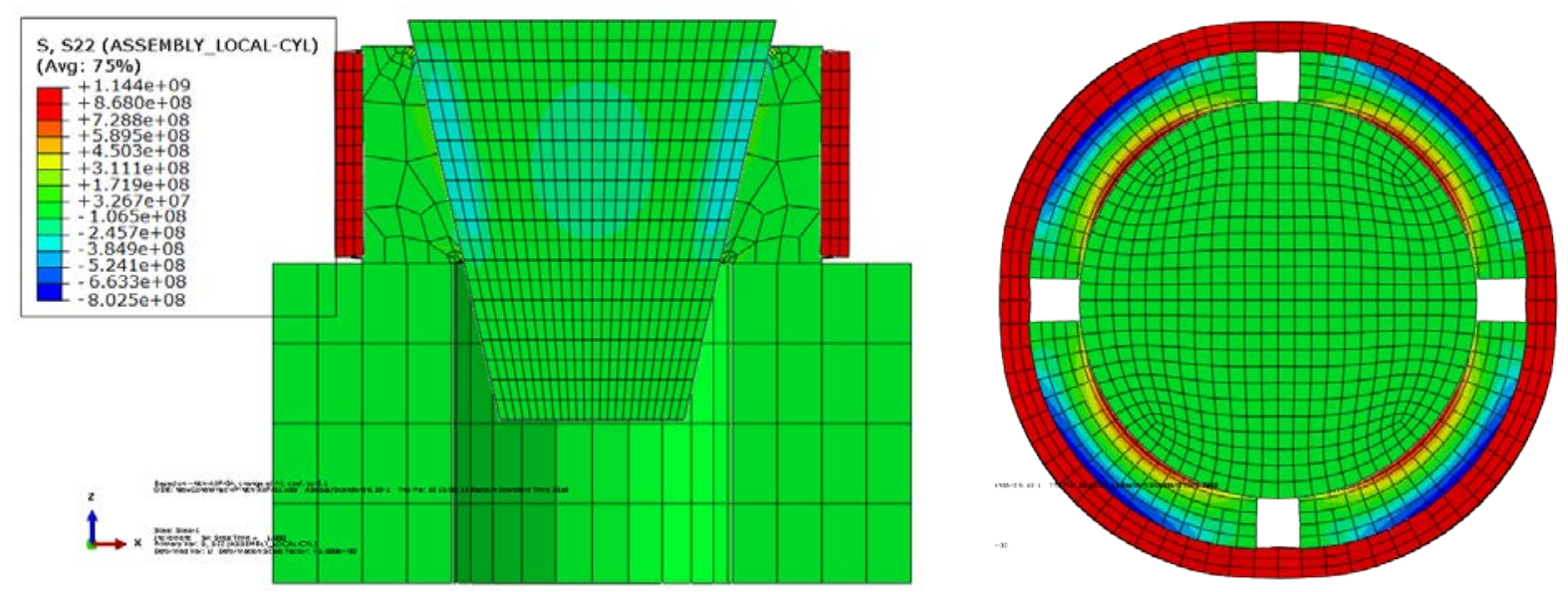

Fig. 4. Uniform stress distribution and uniform deformation in the clad for the cone wedge ring expansion test.

The load transferring mechanism of this newly developed test method is the important improvement compared to its predecessor [50]; this allows the direct input load transmitting from the loading piston to the ring specimen, as shown in Fig. 5. After balancing the force equilibrium equations on the piston cone, the wedges, and the ring, a close-form solution can be derived to explicitly relate the internal pressure on the ring, $p_{2}$, to the piston loading, $F$, from the piston cone, as shown in Eq. (1). Fig. 5 shows shear stress field on the inner surface of the ring due to contact interaction between ring and wedge inserts. The hoop stress $\sigma_{\theta}$, based on thin-wall pressure vessel theory, can be estimated from the internal pressure on the ring but without shear stress field on the inner wall. Thus, internal pressure $p_{2}$ has to be modified with the shear stress field correction factor $\alpha$ to deduct shear stress contribution, as shown in Eq. (2). Finally, by using the thin-wall pressure vessel theory, the hoop stress $\sigma_{\theta}$ can be related to the loading, $F$, by substituting effective internal pressure $p_{2}$, that responsible for deforming the ring, from Eq. (2). The hoop stress $\sigma_{\theta}$ can be further simplified as loading $F$ over the ring specimen thickness and length by using the $\chi$ factor and shear stress correction factor $\alpha$ in Eq. (3). Here the scaling factor $\chi$ is the function of the friction coefficients at the interfaces and the piston cone angle $\theta$, as shown in Eq. (4). Half of the cone 
angle is designed to be $13^{\circ}$. The thickness of the ring specimen, $t$, is $0.584 \mathrm{~mm}$ as received, and the length of the ring specimen is $4.318 \mathrm{~mm}$ as designed.

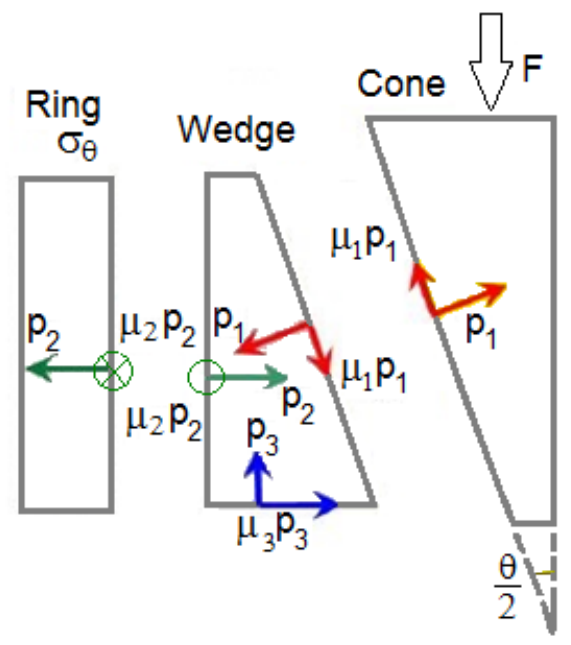

Fig. 5. Schematic for force transferring from loading piston to ring specimen

$$
\begin{aligned}
& p_{2}=\frac{F}{r l} \frac{\left[\frac{1-\mu_{1} * \tan \left(\frac{\theta}{2}\right)}{\tan \left(\frac{\theta}{2}\right)+\mu_{1}}-\mu_{3}\right]}{2 \pi} \\
& p_{2}^{\prime}=p_{2} *(1-\alpha) \\
& \sigma_{\theta}=\frac{p_{2}^{\prime} r}{t}=\chi \frac{F *(1-\alpha)}{t l} \\
& \chi=\frac{\left[\frac{1-\mu_{1} * \tan \left(\frac{\theta}{2}\right)}{\tan \left(\frac{\theta}{2}\right)+\mu_{1}}\right.}{2 \pi} \\
& \text { Hoop Strain }=\frac{\Delta r}{r_{\text {ring }}}
\end{aligned}
$$

where

$P_{2}=$ nominal internal pressure on the ring,

$F=$ loading on the cone,

$\theta=$ cone angle,

$\mu_{1}=$ friction coefficient at cone-wedge interface,

$\mu_{2}=$ friction coefficient at ring-wedge interface,

$\mu_{3}$, = friction coefficient at support-wedge interface,

$P_{2}{ }^{\prime}=$ effective internal pressure for deforming the ring,

$\alpha=$ shear stress contribution factor,

$\sigma_{\theta}=$ hoop stress,

$\chi=$ scale factor, 
$t \quad=$ ring specimen thickness,

$l \quad=$ ring specimen length,

$\Delta r$ = ring total radial dilatation,

$r_{\text {ring }}=$ ring outer radius.

Friction coefficients at the cone-wedge, ring-wedge, and support-wedge interfaces depend on the contact materials and were unknown for the testing. However, frictions between steels at the cone-wedge and support-wedge interfaces are expected be relatively small due to lubricant introduced from machining or directly applied on the surfaces. There was no lubricant applied at ring-wedge interface, in order to minimize the potential relative movement between the ring specimen and the contact wedge during the test. In the FEA simulations, multiple combinations of estimated friction coefficients for three interfaces were investigated, as shown in Table 3. Friction coefficient at cone-wedge interface $\mu_{1}$ and friction coefficient at support-wedge interface $\mu_{3}$ will affect value of $\chi$ factor. While friction coefficient at ringwedge interface $\mu_{2}$ will affect shear stress correction factor $\alpha$.The scaling factor $\chi$ was calculated by using Eq. (4) to convert loading $F$ to hoop stress $\sigma_{\theta}$ in Eq. (3).

Table 3.Friction coefficients at three interfaces and associated $\chi$ factor

\begin{tabular}{|c|c|c|c|}
\hline $\begin{array}{c}\text { Friction coefficient at } \\
\text { cone-wedge interface } \mu_{1}\end{array}$ & $\begin{array}{c}\text { Friction coefficient at } \\
\text { ring-wedge interface } \mu_{2}\end{array}$ & $\begin{array}{c}\text { Friction coefficient at } \\
\text { support-wedge interface } \mu_{3}\end{array}$ & $\begin{array}{c}{\left[\frac{1-\mu_{1} * \tan \left(\frac{\theta}{2}\right)}{\tan \left(\frac{\theta}{2}\right)+\mu_{1}}-\mu_{3}\right]} \\
\chi=\frac{2 \pi}{2}\end{array}$ \\
\hline 0.1 & 0.1 & 0.1 & 0.454 \\
\hline 0.08 & 0.1 & 0.08 & 0.490 \\
\hline 0.07 & 0.1 & 0.07 & 0.509 \\
\hline
\end{tabular}

In FEA simulation results, the pure strain energy for deforming the ring $S E_{\text {ring }}$ is known. Based on Eq. (2), strain energy of the deformed ring in terms of $p_{2}$ ' can be equivalent to the external work produced by the ring internal pressure $p_{2}$ with deduction of shear stress correction factor $\alpha$ in Eq.(7). Substituting Eq.(7) into Eq.(6), the shear stress correction factor $\alpha$ can be estimated in Eq.(8) by further substituting $p_{2}$ from Eq.(1). For instance, for $\mu_{2}=0.1$, the estimate shear stress correction factor $\alpha$ is equal to 0.174 . For a design test set-up system the associated friction coefficients can be effectively estimated through a semiempirical approach that utilizing FEA parameter study and benchmarked with experimental test results.

$$
\begin{aligned}
& p_{2}^{\prime} 2 \pi r l \Delta r=S E_{\text {ring }} \\
& p_{2}^{\prime} 2 \pi r l \Delta r=p_{2} *(1-\alpha) 2 \pi l \Delta r \\
& \alpha=1-\frac{S E_{\text {ring }}}{p_{2} 2 \pi r l \Delta r}
\end{aligned}
$$

The hoop strain can be calculated from radial dilatation $\Delta \mathrm{r}$ from Eq. (5), where $r_{\text {ring }}$ is the ring's outer radius. The outer diameter (OD) of the ring specimen is $9.5 \mathrm{~mm}$. The hoop stress-strain curves for different friction conditions were converted from loading and radial dilatation in the FEA simulations using Eqs. (3) and (4) and were compared with both the tensile data and 10\% increase in tensile data, shown in Fig. 6 . For the different friction coefficients at the contact interfaces and the corresponding $\chi, \alpha$ factor, the resultant hoop stress-strain characterizations were consistent for the same material in the ring specimens. The converted hoop stress-strain matched with the estimated hoop strength, which is $10 \%$ increase in the tensile data. 


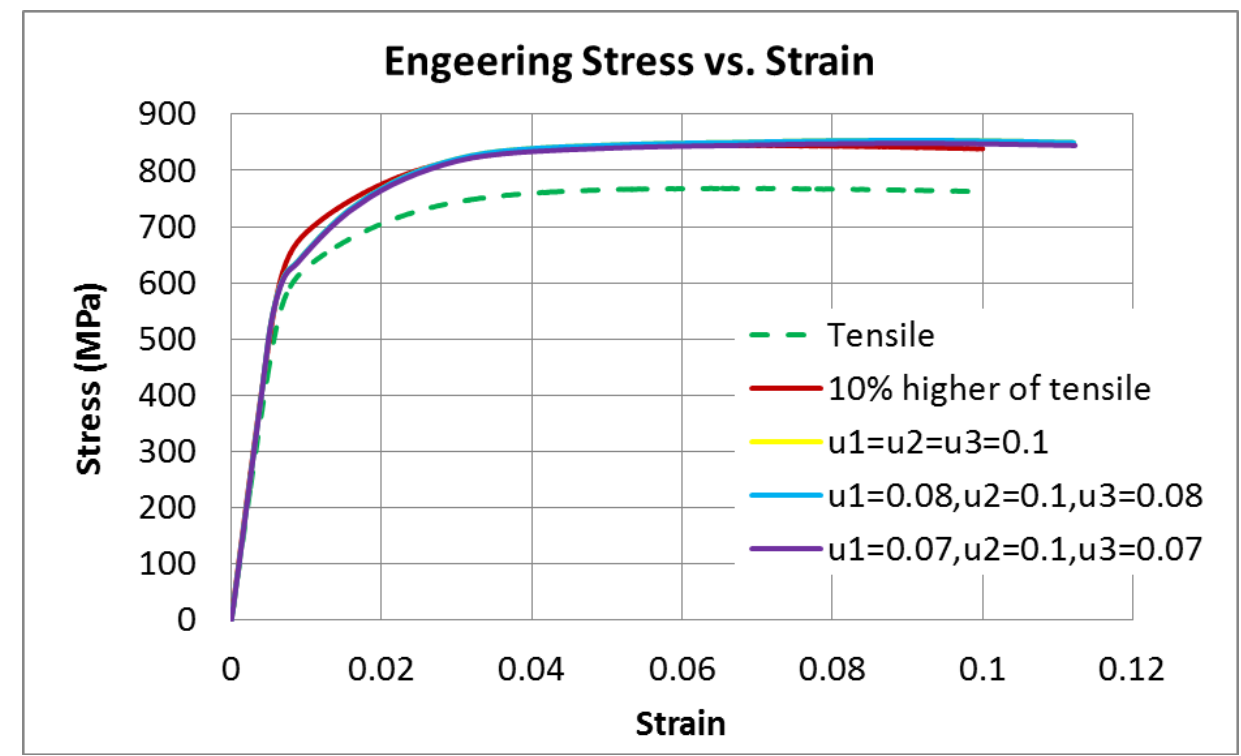

Fig. 6. FEA hoop stress-strain curves vs. tensile test data for the cone wedge ring expansion test method.

\section{PILOT TEST FOR VERIFYING CONE WEDGE RING EXPANSION TEST DESIGN}

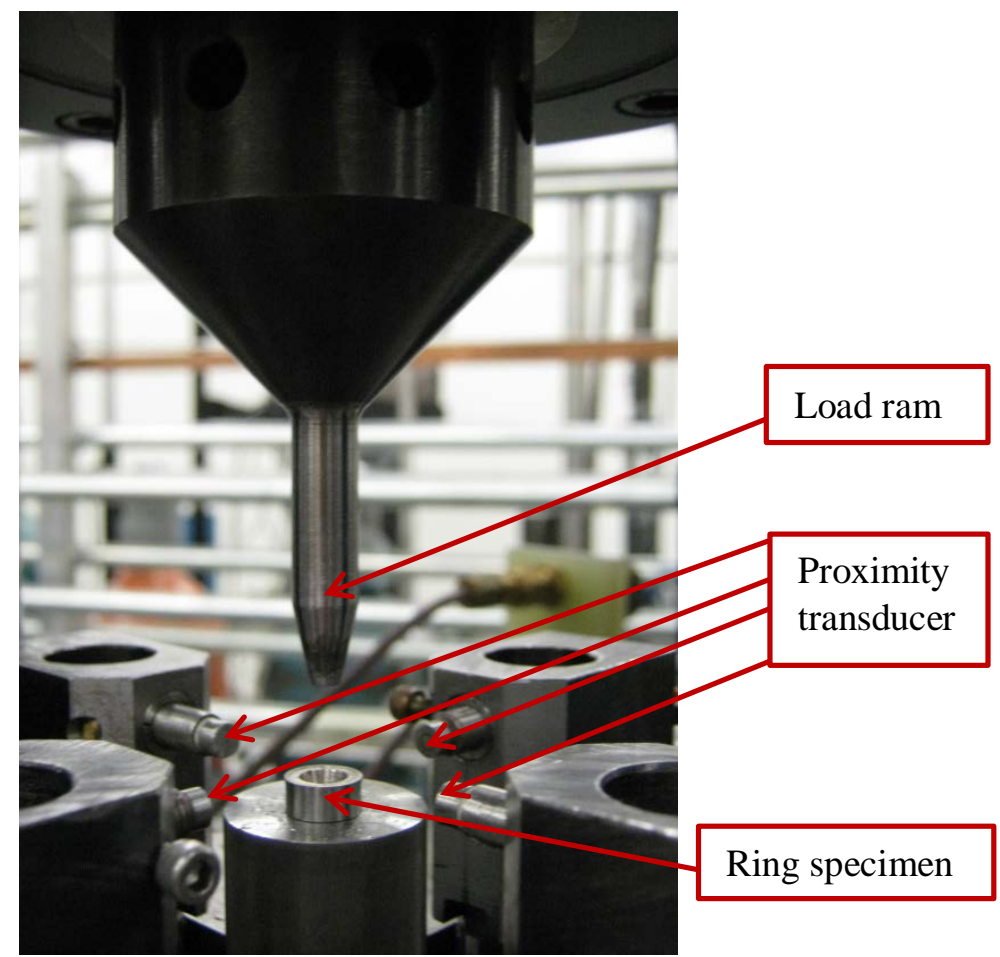

Fig. 7. Test setup for verifying cone wedge ring expansion test design.

The MTS RT/50 screw-driven test machine was used to apply an axial compressive load to the piston cone. The cone pushed against the four pieces of the wedge insert and caused them to move outward radially to achieve radial expansion of the tested ring specimen. Measurements were made of the total applied load, the extension of the piston cone, and the radial expansion of the ring during the test. The radial expansion of the ring specimen was measured with four proximity transducers (Fig. 7), and the result was used to calculate the circumferential strain. The load and radial expansion data can be 
converted into material stress-strain curves to examine the mechanical properties of the tested ring specimen, such as the Young's modulus, yield strength, and strain-hardening characteristics. The pilot test was performed at room temperature in an out-of-cell environment.

When ring specimens are tested by the cone wedge ring expansion test method (Fig. 7), the steel wedges are rigid and free to move, and they were designed to transfer the load without physical deformation. The applied load on the piston cone can be transferred directly through the steel wedges to the test ring. Compared with the previous expansion plug wedge test, the cone wedge ring expansion test method is more direct and spontaneous without the plug as an intermediary. Furthermore, in the expansion plug wedge test, the test needs to be performed on the plug separately to deduct the load or energy on the plug; that procedure is not needed in the cone wedge ring expansion test. Thus, the new testing protocol saves significant effort compared with the plug testing procedure.

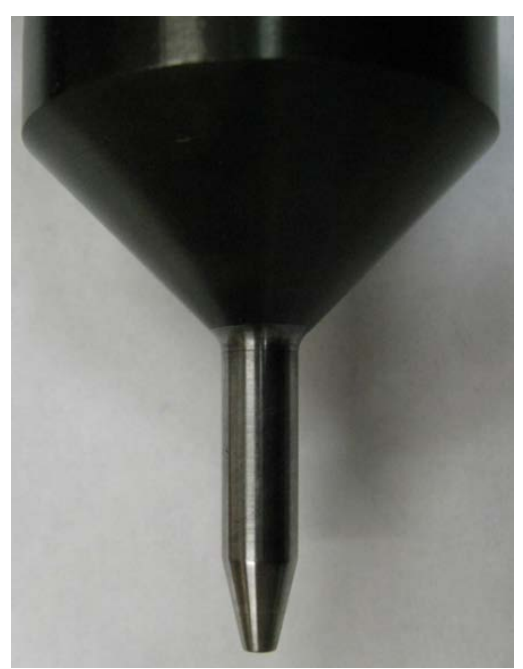

Top loading piston

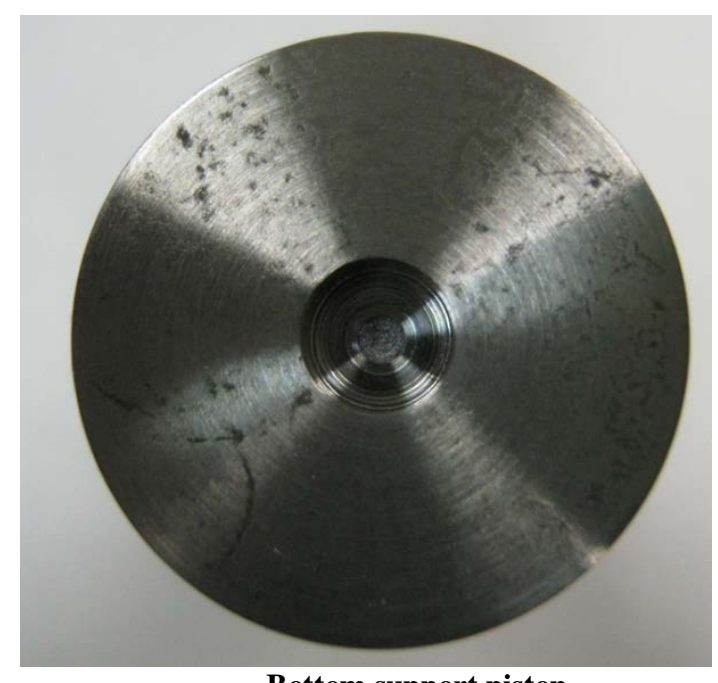

Bottom support piston

Fig. 8. Cone-shaped loading piston and a hole on the bottom support piston.

The geometry of the cone wedge ring expansion test system was optimized through FEA simulation. For example, the ring specimen length was designed for more uniform stress and strain distribution within the gage section. To verify the test method, the test specimen was fabricated based on an FEA design. As shown in Fig. 8, the top loading piston was machined to the cone shape with a half angle designed as $13^{\circ}$. The bottom support piston had a shallow hole, $5.08 \mathrm{~mm}$ deep and $5.588 \mathrm{~mm}$ in diameter, to house the cone piston when the cone piston penetrated the wedge inserts. Because of the lateral confinement provided by the ring, the cone piston and the matching wedge surfaces were automatically aligned during the testing under the downward movement of the cone piston.

In the pilot tests, carried out at room temperature, the baseline $\mathrm{Zr}-4$ cladding tube sample had an OD of $9.5 \mathrm{~mm}$ and a thickness of $0.584 \mathrm{~mm}$; the dimensions were determined by FEA simulation. The ring specimens were machined from the Zr-4 clad tubing with an optimized length of $4.318 \mathrm{~mm}$. The wedge insert sections were made of hardened tool steel. They were the same length as the ring and were designed to fit into the inner diameter (ID) of the test ring. Using the ring specimen as a holder, the wedge ring was machined to have a tapered surface matching that of the cone piston. The formed wedge ring had a taper angle of $13^{\circ}$, and the thicknesses at its top and the bottom were 1.092 and $2.083 \mathrm{~mm}$, respectively. Then the wedge ring was cut into four pieces to form the wedge insert. Two sets of the four wedge insert pieces were machined with the ring specimens in place to serve as lateral confinement. This inevitably generated significant residual stress within the ring specimen during machining of the wedge insert and resulted in the permanent deformation that enlarged the ring radius. 
Figure 9 shows two untested Zr-4 ring specimens with wedge inserts. The wedges were machined in situ with ring specimens 1 and 2 serving as radial lateral confinement. There was evidence of the enlarged radius dimensions on ring test specimens 1 and 2 due to machining of the wedge inserts; limited or no gaps were observed between the wedge inserts or between the rings and the wedge inserts. Neither end of the ring specimen could contact the pistons, avoiding shear stress applied onto the top or bottom surfaces of the ring. This arrangement reduced the potential of developing complex stress states within the tested ring.
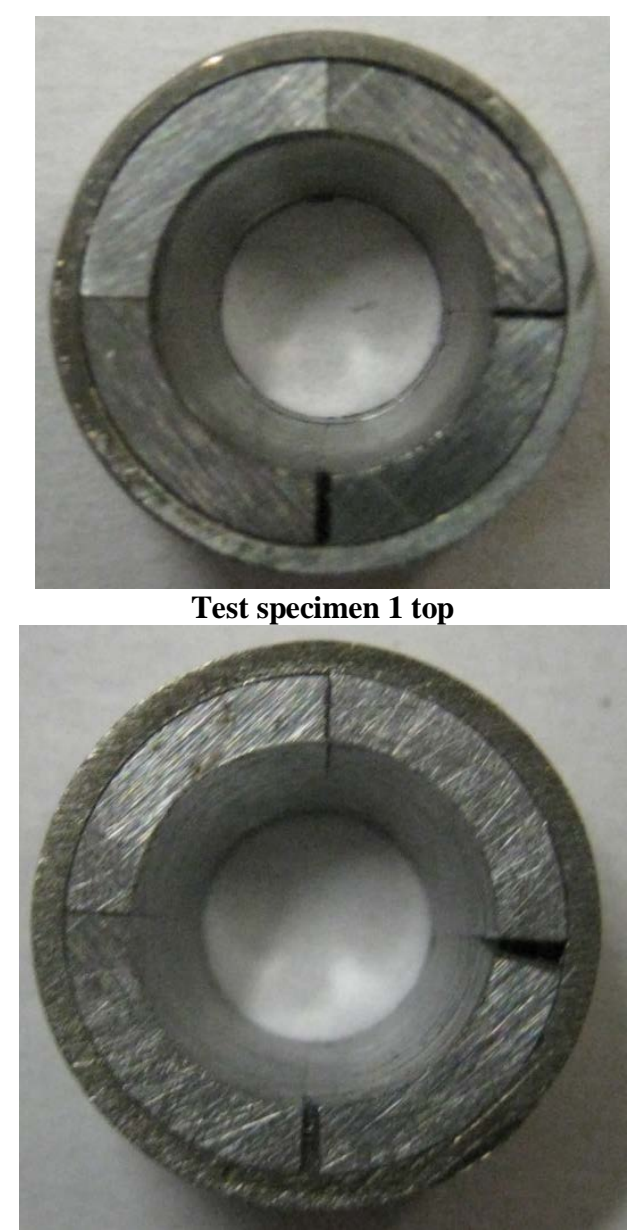

Test specimen 2 top

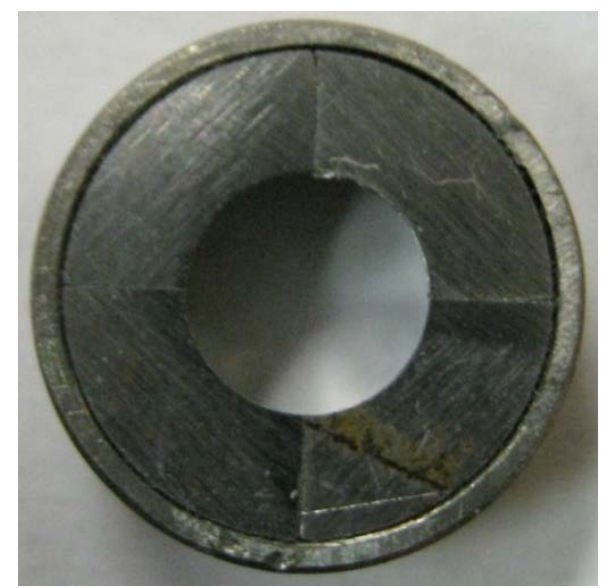

Test specimen 1 bottom

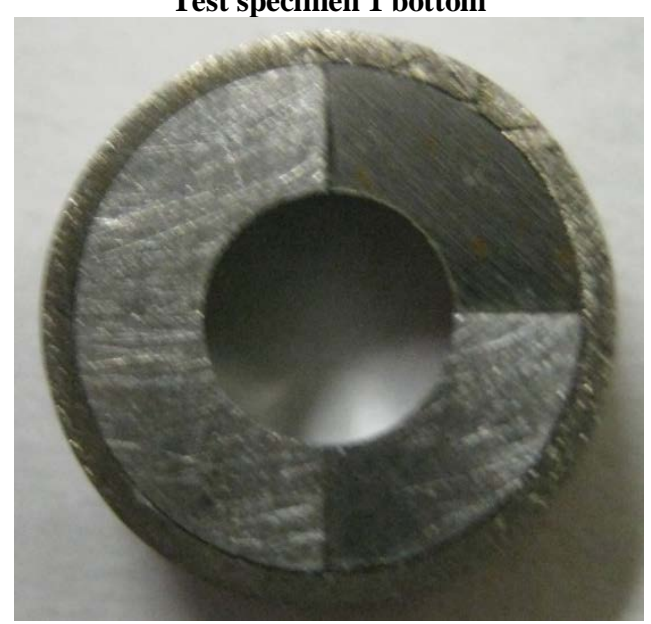

Test specimen 2 bottom

Fig. 9. Untested Zr-4 ring specimens with the first two sets of the fabricated wedge inserts.

A total of four ring specimens were tested using these two sets of wedge inserts, as shown in Fig. 10. For ring test specimens 3 and 4 , the developed wedge insert pieces needed to be forced into the ring specimens. This also caused a minor pre-test deformation of the test ring specimens. However, it was expected that ring specimens 3 and 4 would experience much less plastic deformation and the associated residual stress than did ring specimens 1 and 2 . The ring deformation phenomenon was further validated through test results. For testing ring specimens 1 and 2, the loading piston moved downward $2.032 \mathrm{~mm}$ with a loading rate of $1.27 \mathrm{~mm} / \mathrm{min}$. The test specimens didn't fail, but they showed necking at the wedge opening locations.

For testing ring specimens 3 and 4, the loading piston moved downward $3.048 \mathrm{~mm}$ and $2.54 \mathrm{~mm}$, respectively, with a loading rate of $1.27 \mathrm{~mm} / \mathrm{min}$; and the ring specimens were successfully tested to final fracture. The specimens ruptured at the open gap section between the wedge inserts. A through-thickness 
crack line perpendicular to the hoop direction was observed at the center of the ring, and then the crack further fractured through the specimen at a $45^{\circ}$ angle to the principal hoop stress direction. This finding indicates that a ductile tensile failure mode of void coalescence was initiated at the center of the ring, and then the crack propagated to the end of the specimen in a ductile shear failure mode soon after the through-thickness crack (perforated hole) developed to a critical length (Fig. 10). Furthermore, the ring specimens deformed uniformly in the circumferential direction, as observed in the top view of Fig. 10. The side view also shows that the ring specimens deformed uniformly in the axial direction, and no bulging effect was observed on the deformed ring specimen.
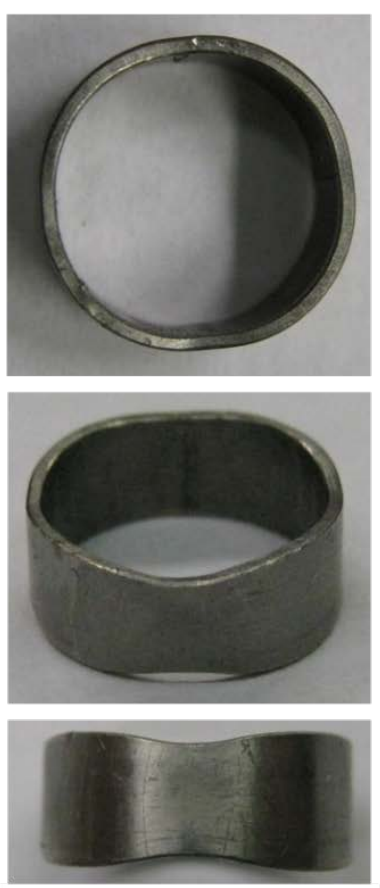

Test\#1-compression extension to $2.032 \mathrm{~mm}$, speed $1.27 \mathrm{~mm} / \mathrm{min}$, test specimen didn't fail.
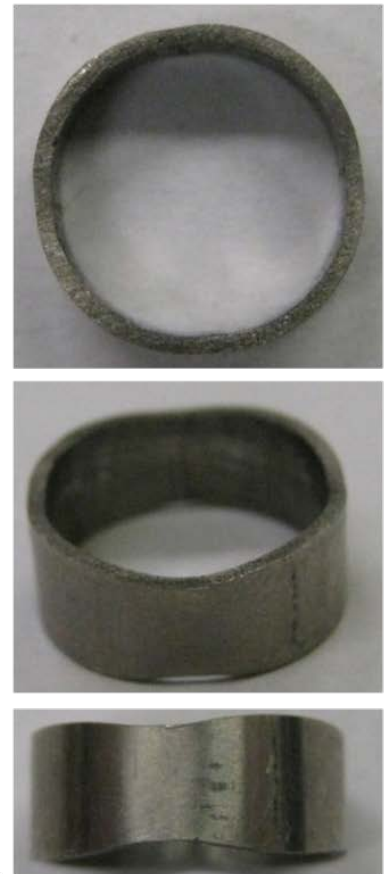

Test\#2-compression extension to $2.032 \mathrm{~mm}$, speed $1.27 \mathrm{~mm} / \mathrm{min}$, test specimen didn't fail.
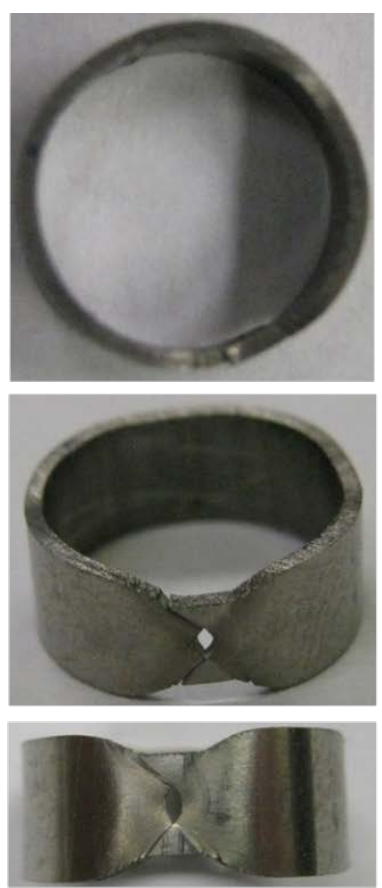

Test\#3-compression extension to $3.048 \mathrm{~mm}$, speed $1.27 \mathrm{~mm} / \mathrm{min}$, test specimen failed.
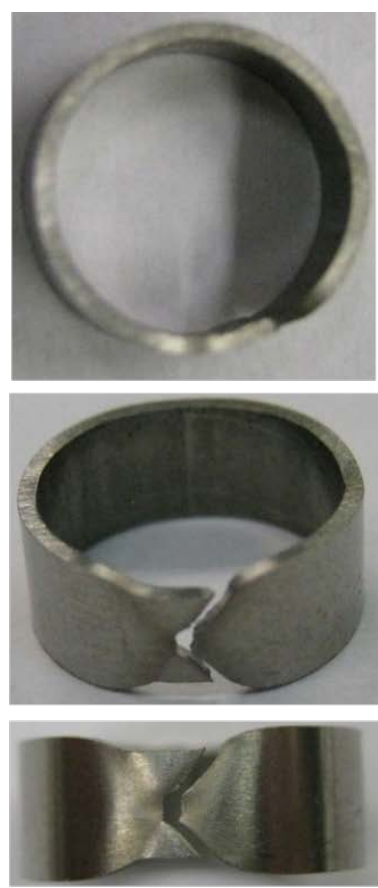

Test\#4-compression extension to $2.54 \mathrm{~mm}$, speed $1.27 \mathrm{~mm} / \mathrm{min}$, test specimen failed.

Fig. 10. Tested Zr-4 ring specimens using the first fabricated wedge inserts.

Figure 11 shows test results for the ring specimens with the two sets of fabricated wedge insert pieces. As mentioned earlier, these inserts were machined in situ with ring specimens 1 and 2 serving as lateral confinement. The machining caused permanent dilation and residual stresses on ring specimens 1 and 2, in addition to affecting the quality of the surfaces of the wedges tapered to fit well with the cone-shaped loading piston. As a result, the measured load and extension data are not smooth at the elastic region. Furthermore, for ring specimens 3 and 4, the wedges were force-fitted into the ring specimens, which caused some degree of pre-deformation of the ring specimens. However, its intensity was much less than in specimens 1 and 2 because of the in situ machining of the wedge inserts. The deformation phenomenon was clearly revealed in the test results, which show that the maximum piston compression loads for test 3 and test 4 are much higher than those for test 1 and test 2 (Fig. 11). 


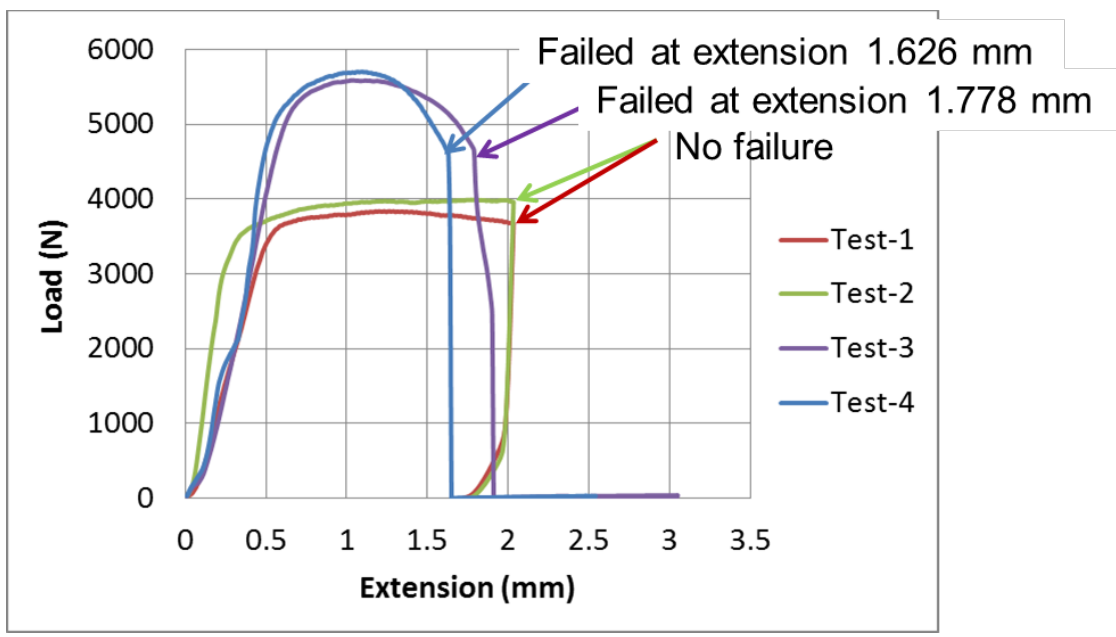

Fig. 11. Test data for ring specimens tested with the first fabricated wedge inserts

To avoid pre-deformation in the ring specimens and improve the tapered surface of the wedge for a better fit with the cone-shaped loading piston, a new wedge ring was machined within a high-strength steel mold ring with a thickness five times that of the ring specimen to develop the tapered surface. Then the wedge ring was cut into four pieces. The OD of the wedge was made $0.0254 \mathrm{~mm}$ smaller than the ring specimen ID so that the wedge inserts could be easily installed into the ring specimens. The completed new wedges were inserted in the ring specimens, and the observed minor gaps between the wedges and the ring indicated that pre-deformation was no longer occurring in the ring specimens, as shown in Fig. 12.
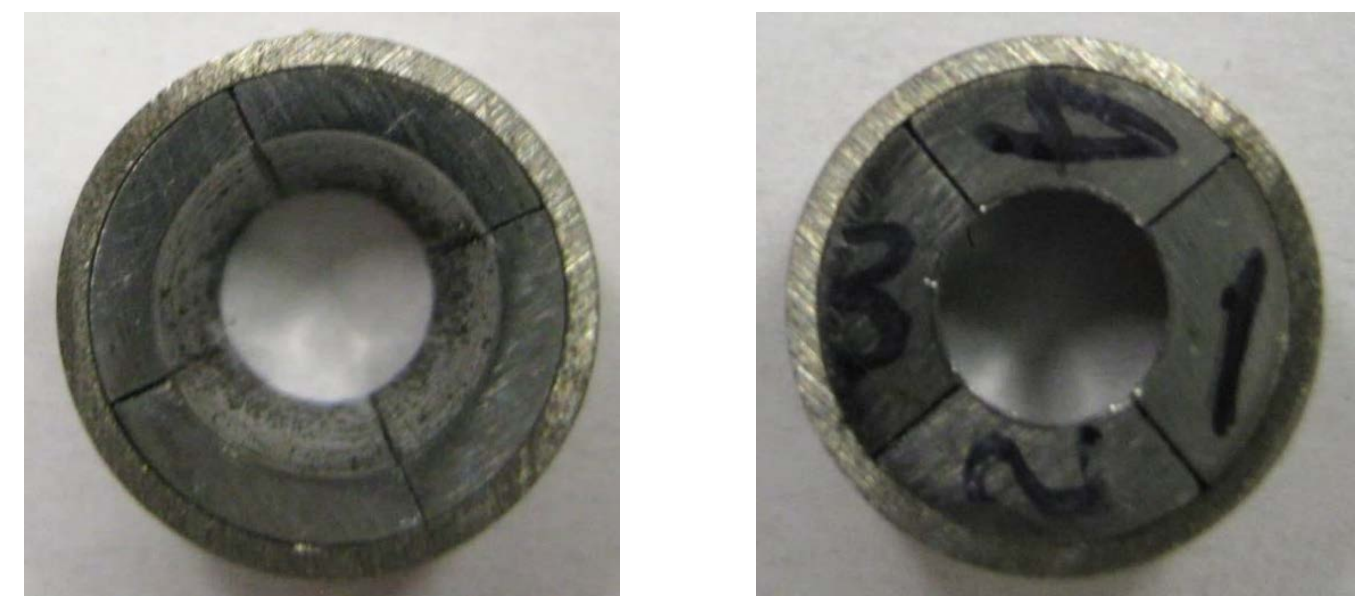

Fig. 12. Untested Zr-4 ring specimen with the new fabricated wedge inserts.

Figure 13 shows the ring specimen with the newly fabricated wedge insert mounted on the cone-shaped loading piston for a pre-test check-up. The tapered surfaces of the wedge fitted well with the cone-shaped piston. 


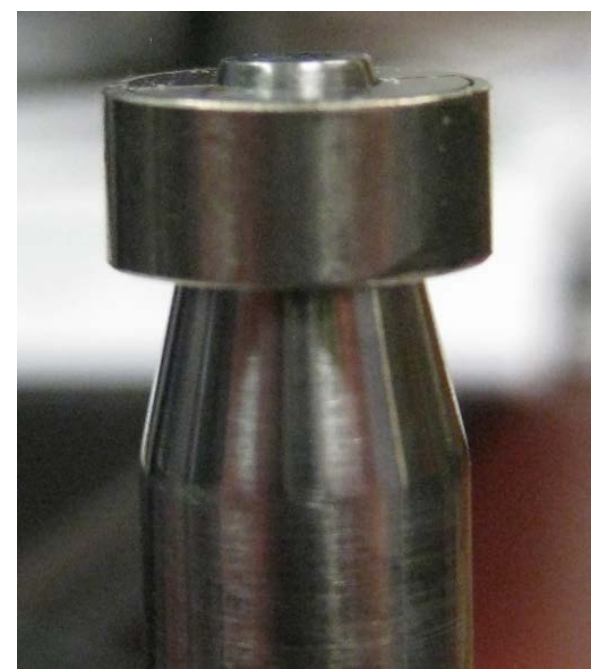

Fig. 13. Ring specimen with tapered wedge well matched with the cone-shaped piston.
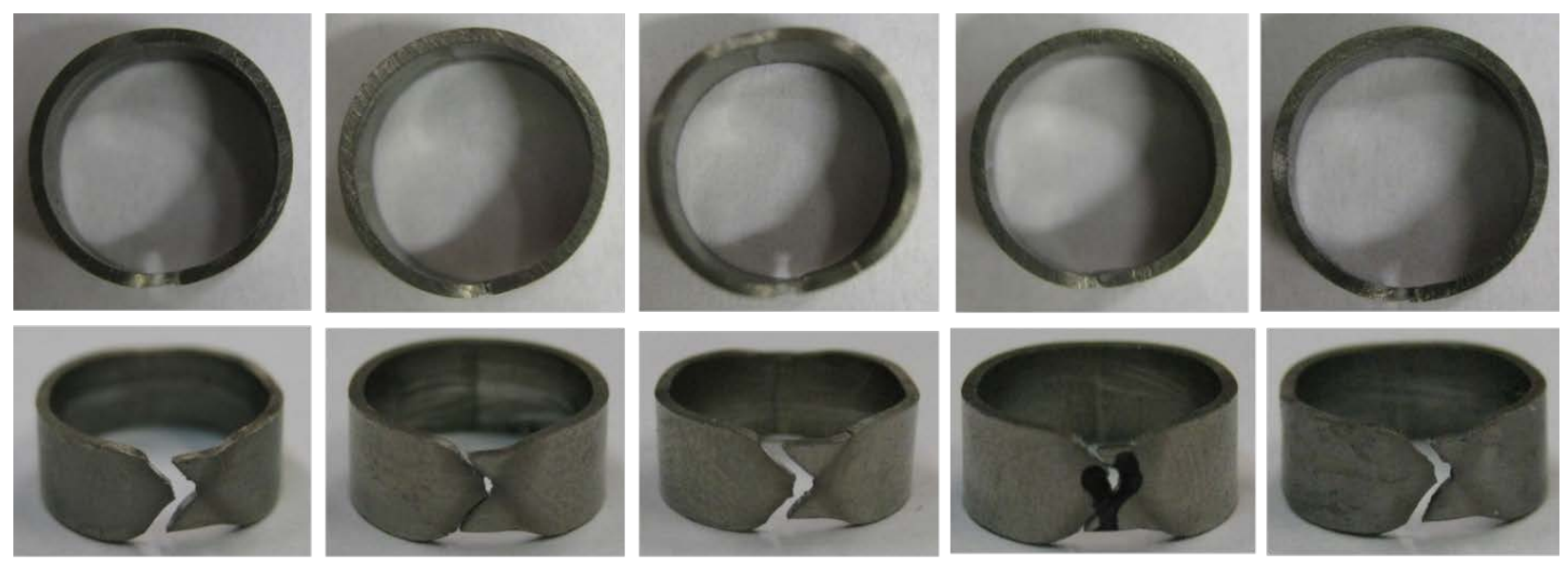

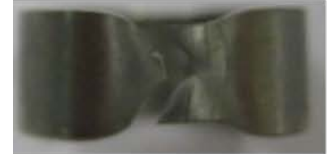

Test-NW\#1:

compression extension speed $0.254 \mathrm{~mm} / \mathrm{min}$, to failure

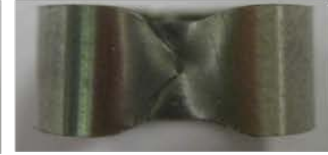

Test-NW\#2: compression extension speed $0.635 \mathrm{~mm} / \mathrm{min}$, to failure

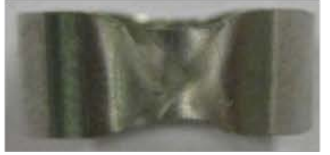

Test-NW\#3: compression extension speed $0.254 \mathrm{~mm} / \mathrm{min}$, to failure

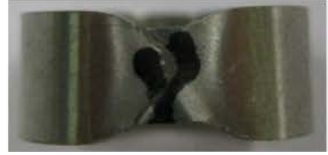

Test-NW\#4: compression extension speed $0.254 \mathrm{~mm} / \mathrm{min}$, to failure

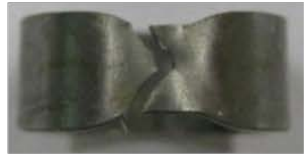

Test-NW\#5: compression extension speed $0.254 \mathrm{~mm} / \mathrm{min}$, to failure

Fig. 14. Tested $\mathrm{Zr}-4$ ring specimens using the new wedge inserts.

Five ring specimens were tested with this new set of wedge inserts, as shown in Fig. 14. Based on the earlier experience of testing ring specimens with the first two sets of wedge inserts, the compression extension downward movement now was set at $2.54 \mathrm{~mm}$ for all five tests to ensure that the test samples would reach the final fracture state. The extension loading rate was reduced to $0.254 \mathrm{~mm} / \mathrm{min}$ to observe the potential material loading rate effect and to allow the tested specimen sufficient time to redistribute its input energy profile to resemble quasi-static loading behavior. Except for test NW\#2, the extension loading rate was set to $0.635 \mathrm{~mm} / \mathrm{min}$ to allow study of the loading rate effect. The tested ring specimens all reached final fracture failure. Similar fracture modes were observed compared with the earlier tested sets. The ring specimens deformed uniformly in the axial and circumferential directions (Fig. 14). 
Fig. 15a shows the measured load and piston compression extension for the ring specimens tested with the new wedge inserts. Fig. 15b shows the measured load vs. the radial dilatation for the ring tests. The test data show a much smoother response in the elastic region than the test results for the wedges fabricated earlier. Test data appeared to be self-consistent among all the tests. For the target loading rate, the load trends appeared to gradually increase to the maximum or ultimate and then gradually drop as a result of necking until the ring reached final fracture failure. The test results seem to indicate a loading rate effect, in which the NW\#2 specimen with the higher loading rate showed slightly higher yield stress and lower ductility.

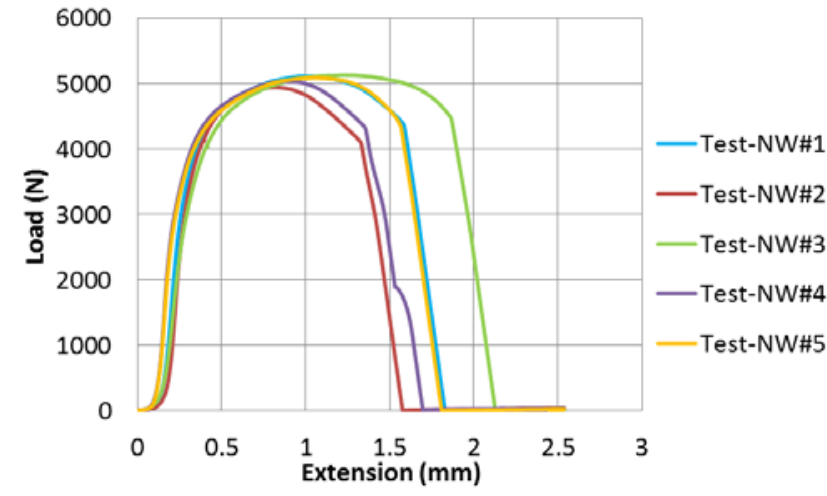

(a) Load vs. Extension

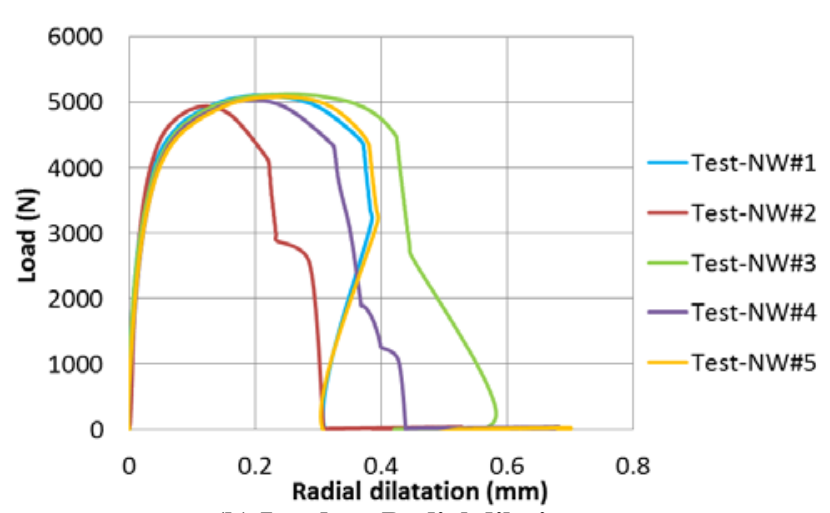

(b) Load vs. Radial dilation

Fig. 15. Test data for ring specimens tested with the new wedge inserts.

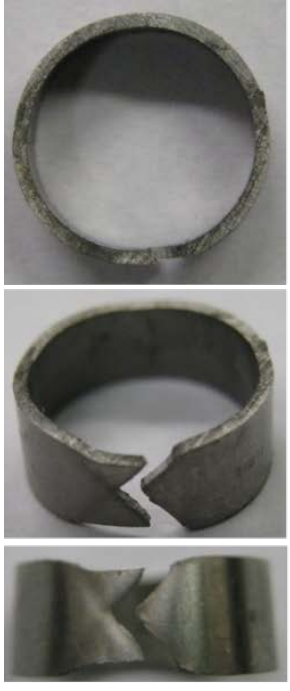

Test-NW\#6: compression extension speed $1.27 \mathrm{~mm} / \mathrm{min}$, to failure

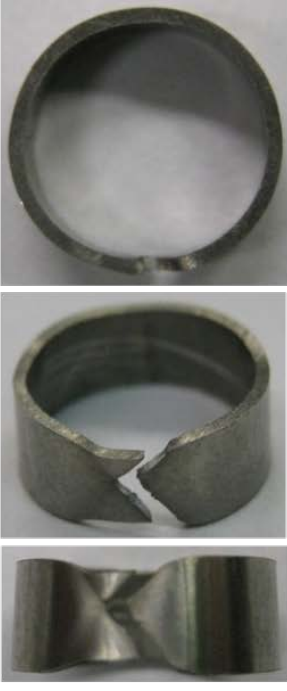

Test-NW\#7: compression extension speed $1.27 \mathrm{~mm} / \mathrm{min}$, to failure

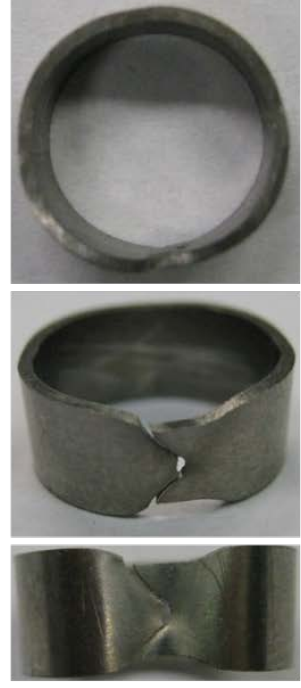

Test-NW\#8: compression extension speed $0.635 \mathrm{~mm} / \mathrm{min}$ to failure

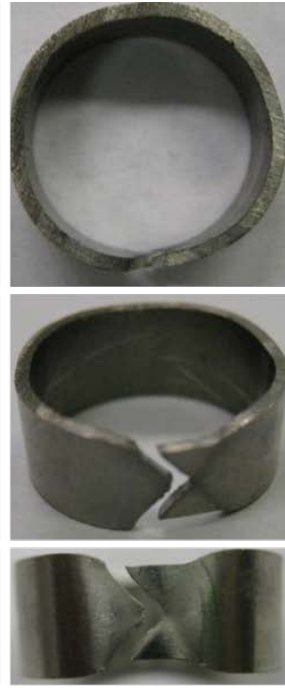

Test-NW\#9: compression extension speed $0.254 \mathrm{~mm} / \mathrm{min}$, to failure

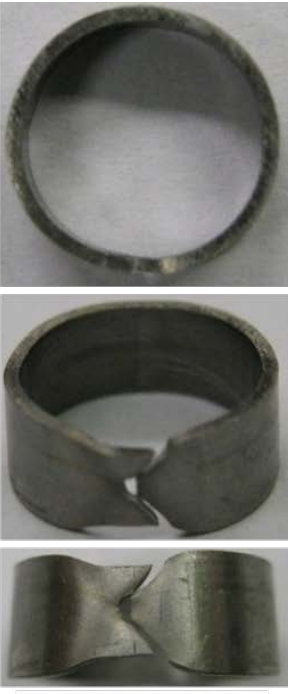

Test-NW\#10: compression extension speed $0.127 \mathrm{~mm} / \mathrm{min}$, to failure

Fig. 16. Tested Zr-4 ring specimens using the new wedge inserts under different loading rates.

To further investigate the potential impact of loading rates on mechanical properties obtained from the proposed method, another set of five rings were tested using the same cone wedge method under different loading rates. (see Fig. 16). The compression extensions were still set at $2.54 \mathrm{~mm}$ for all five tests. Ring specimen 6 and 7 were tested under a high loading rate of $1.27 \mathrm{~mm} / \mathrm{min}$. Ring specimen 8 was tested 
under median loading rate of $0.635 \mathrm{~mm} / \mathrm{min}$. Ring specimen 9 and 10 were tested under low loading rates of $0.245 \mathrm{~mm} / \mathrm{min}$ and $0.127 \mathrm{~mm} / \mathrm{min}$, respectively. Compared with the test data for specimens 6 and 7 versus the data for specimen 10, which show a 10 times different in loading rates, the failure modes showed quite different profiles. The failure of tested specimens 6 and 7 initiated at the center of necking region and then propagated in shear failure mode along the maximum shear stress contour, whereas the failure of test specimen 10 initiated at the center of the necking region and propagated along the hoop orientation. After reaching a critical length, it then propagated in an axial direction. Then from two weakest points along a shear band, it propagated along the maximum shear stress direction in shear failure mode. The failure of tested specimens 8 and 9 had a similar pattern to that of specimen 10 .

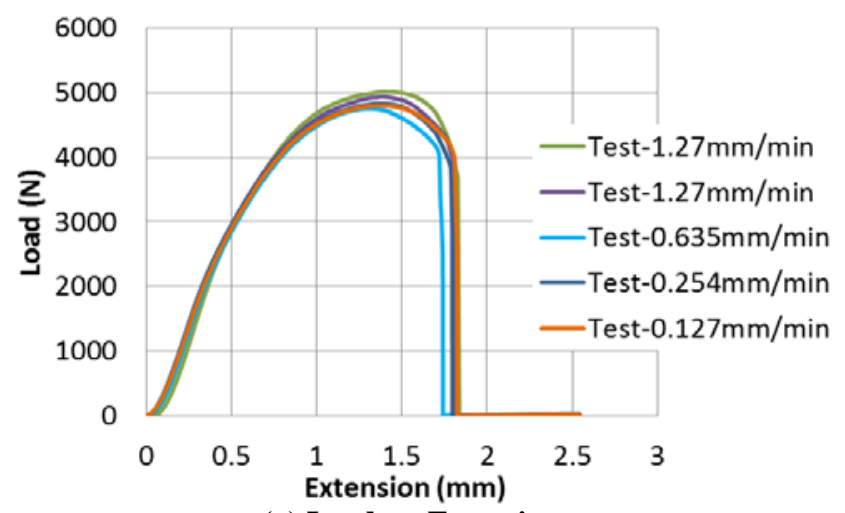

(a) Load vs. Extension

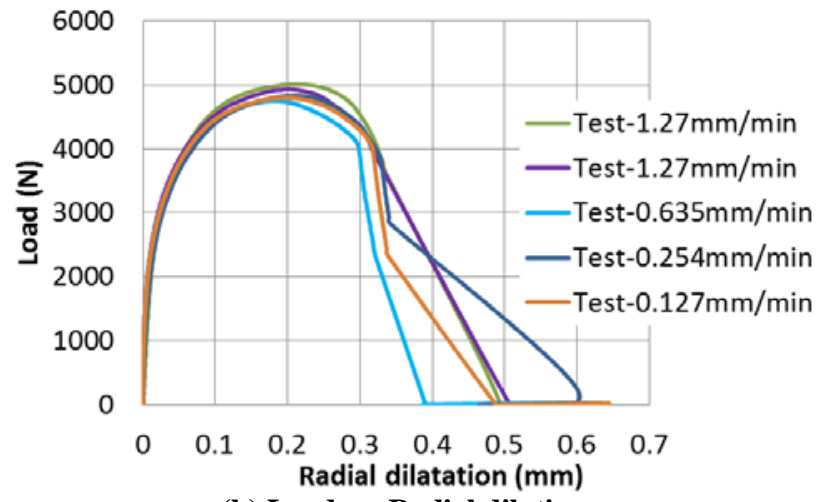

(b) Load vs. Radial dilation

Fig. 17. Test data for ring specimens tested with the new wedge inserts under different loading rates

However, the load and ductility compared in Fig. 17 only show slight changes for all the tests under different loading rates. The results indicate that the impact of loading rates between $0.127 \mathrm{~mm} / \mathrm{min}$ and $1.27 \mathrm{~mm} / \mathrm{min}$ would be very small for the cone wedge ring test method. A loading rate of $0.254 \mathrm{~mm} / \mathrm{min}$ is recommended for consideration for smoother data processing and a reduced need for data storage. All the test data can be used to interpret material stress-strain characteristics.

\section{TEST DATA CONVERTING TO HOOP STRESS-STRAIN CURVE}

As discussed in Section 2, a close-form solution was developed to convert the measured load into hoop stress using the $\chi$ factor. The test data processing was simple and straightforward. By applying Eqs. (3) (5), the measured load on the piston and the radial dilatation of the ring specimen could be directly converted into a hoop stress-strain curve. However, the friction coefficients at various contact surfaces, such as piston cone and wedges, ring and wedges, and support base and wedges, were unknown in the testing. The $\chi, \alpha$ factor in Eq. (3) could not be determined without knowing the friction coefficients at those interfaces.

The measured load-extension data obtained from the cone wedge ring expansion test were compared with FEA simulation results with different friction estimations (see Fig. 18). In the FEA simulations, the $10 \%$ increase of uniaxial tensile test data were used as input to represent the hoop tensile characteristics. From the literature, the anisotropic character of the $\mathrm{Zr}-4$ material shows that the hoop strength is normally higher than the axial tensile strength. The estimated hoop tensile data are within the range of literature data. The FEA simulation used the same material and the same methodology as the testing system, thus, the load and the displacement estimated from FEA simulation, with proper friction coefficients estimated, should be equal or close to that obtained from the test measurement data. The FEA load-extension data showed friction coefficients of 0.07 at the cone-wedge and the support wedge interfaces and 0.1 at the ring-wedge interface matched with those from the cone wedge ring testing data (Fig. 18a). Other two FEA 
estimations were higher than the testing data. This indicates that the friction coefficients in the existing testing system were close to 0.07 at the cone-wedge and the support wedge interfaces and 0.1 at the ringwedge interface. The work generated from testing data and FEA data with different friction coefficients were compared in Fig. 18b. Again, the work from FEA estimation with friction $\mu_{1}=0.07 \mu_{2}=0.1 \mu_{3}=0.07$ agreed well with testing data.

In Fig. 18, the test extensions were adjusted with system compliance. In the elastic region, the FEA results matched well with the test data. However, the FEA simulation results appeared to be flat at a high extension level and did not show a significant load drop because of necking and failure. This is because no failure criteria were defined in the FEA simulation in addition to the uniaxial tensile property given in the models. Thus, the FEA simulations were not able to properly simulate the post-necking clad material response and the final failure.

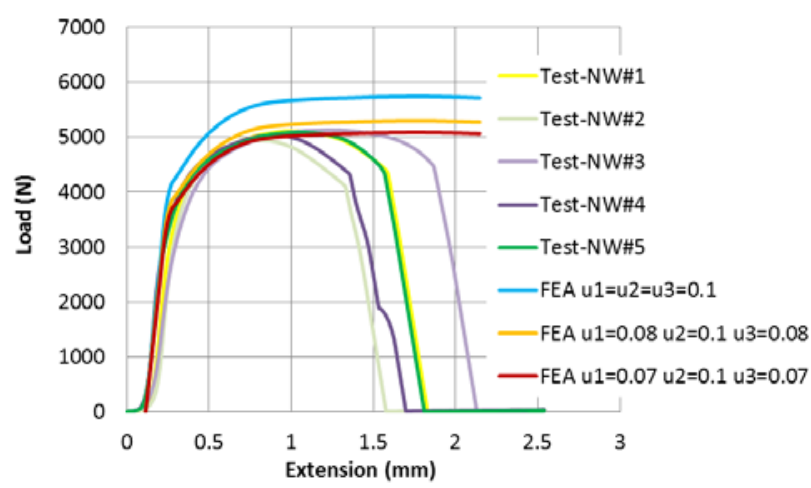

(a)

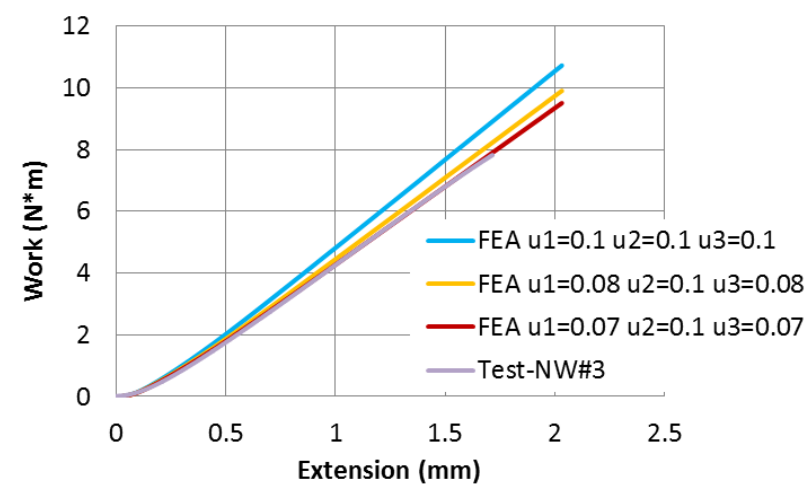

(b)

Fig. 18. Load-extension data comparison between tests and FEA simulations with different friction estimations.

The friction coefficients of the test system were estimated as $\mu_{1}=0.07$ at the cone-wedge interface, $\mu_{2}=0.1$ at the ring-wedge interface, and $\mu_{3}=0.07$ at the support-wedge interface with assistance of FEA. A corresponding $\chi$ factor of 0.509 and $\alpha$ factor of 0.174 were used to process all ten test data sets; the converted hoop stress-strain curves were compared with the uniaxial tensile test data, as shown in Fig. 19.

In the elastic region of Fig. 19, all of the test data were quite consistent with one another. In the strain hardening region before necking, the hoop stress-strain curves of the ring test data followed the general strength hardening trend of the uniaxial tensile test data, except that the maximum hoop stress level of the ring test data was about $10 \%$ higher than that of the tensile test data. The measured load-displacement data using the cone wedge ring expansion test method were successfully converted into a hoop stressstrain characterization of the ring material using the close-form solution and the associated $\chi$ and $\alpha$ factor.

In general, the strength difference between the axial and hoop orientations varied by $0-20 \%$ from the literature data in Table 1. In this study, the Zr-4 clad tubing was tested as received, and the history of the material treatment and manufacturing is unknown. The estimated hoop tensile data are about $10 \%$ higher than the uniaxial tensile tube test data; the difference is within the range of the literature data. 


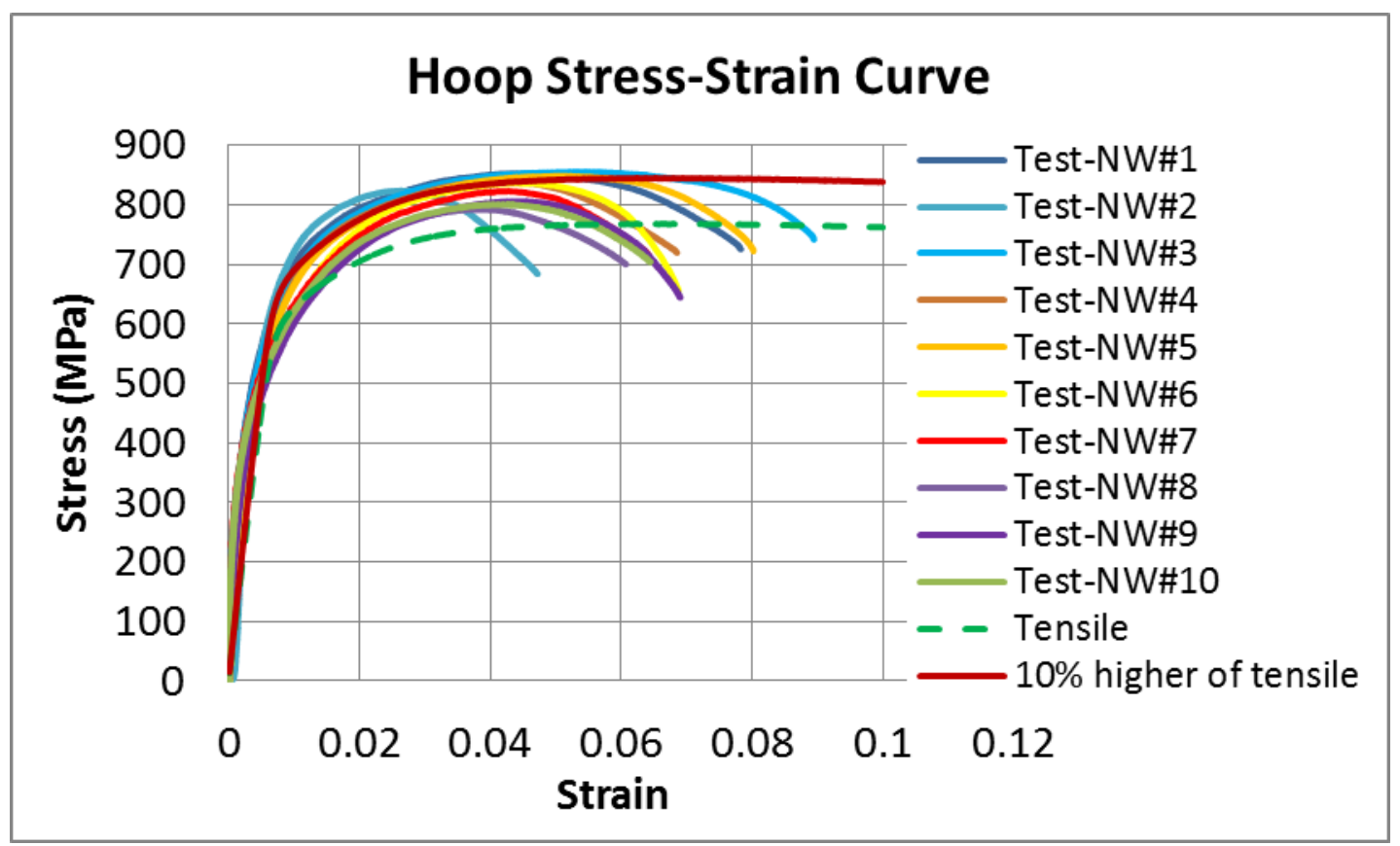

Fig. 19. Converted hoop stress-strain curves of ring test data compared with uniaxial tensile tube test data.

\section{CONCLUSION}

A cone wedge ring expansion test method based on Nilsson et al. [50] was designed and developed to determine the hoop tensile properties of irradiated fuel cladding in a hot cell. Four-piece wedge inserts were designed with a tapered angle to match the shape of a cone-shaped loading piston. The ring specimen was expanded in the radial direction by the compressive force transferred from the loading piston through the wedges to the ring. The proposed test method is designed to be simple and can be easily implemented in a hot cell.

FEA simulation results showed uniform stress and strain distribution at the gage section of the ring specimen using the cone wedge ring expansion test method. One of the advantages of this newly developed test method is the effective force transfer from the loading piston to the ring specimen. A close-form solution was derived to explicitly relate the hoop stress $\sigma_{\theta}$ to the loading from the piston cone using the $\chi$ factor. The scaling factor $\chi$ is the function of the friction coefficients at interfaces and the piston cone angle. By applying the $\chi$ factor, the load of the driving piston and the radial dilatation of the ring can be successfully converted to hoop stress-strain curves. Literature data show anisotropic material behavior for the baseline $\mathrm{Zr}-4$ cladding. The difference between the axial and the hoop stress varied by 0 $20 \%$ (Table 1).

Based on FEA design and simulation efforts, the ring specimens and wedge inserts were fabricated accordingly for further test validation. The loading piston was machined with the designed cone shape and a supporting piston was machined with a shallow hole to house the loading piston after it penetrated the wedge inserts. The geometries of the ring specimen sets in the pilot test were optimized through FEA design. The length of the $\mathrm{Zr}-4$ ring was set to $4.318 \mathrm{~mm}$, and the wedge was machined to have a tapered surface matching that of the cone-shaped loading piston. The fabrication of the wedge inserts was improved during several iterations of the pilot tests. The newly upgraded wedges have the same length as the test ring, and the OD was machined to be $0.0254 \mathrm{~mm}$ smaller than the ring ID to allow easy 
installation. Nine pilot tests were performed on the $\mathrm{Zr}$-4 ring specimens using the cone wedge expansion test method. With the new wedge inserts, five ring specimens were successfully tested to failure. The test specimens appeared to fail under tensile testing initially at the center of the ring specimen, with a crack then propagating through the specimen in a shear failure mechanism. The tested ring specimens deformed uniformly in the axial and circumferential directions.

With the friction coefficients at the interfaces estimated and calibrated from FEA simulation and test results, the $\chi$ and $\alpha$ factor were determined to be used for processing the test data. The close-form solution and the associated $\chi$ and $\alpha$ factor were applied directly to extract the hoop mechanical properties of the fuel cladding based on measured load-displacement data obtained from the cone wedge ring expansion test. The estimated hoop tensile strength based on the ring test data was about $10 \%$ greater than that based on the tensile test data. The variation in test results between the cone wedge ring expansion test and the tubing uniaxial tensile test was within the range of the literature review data.

Based on the proposed test method and the optimized test specimen design, as well as the data processing procedure, the cone wedge ring expansion test protocol validated that the measured piston load, compression extension, and ring radial expansion can be effectively and accurately converted into a hoop stress-strain curve for clad tubing material characterization. The test method is simple and can be easily implemented in hot cell or high-temperature environments.

\section{FUTURE WORK}

Further detailed study is needed on this subject. The following are proposed tasks for developing the cone wedge ring expansion test.

Task 1: Perform pilot testing on Zr-4 clad specimens to further validate the test method and procedure.

Task 2: Develop a pilot testing protocol to accommodate high-temperature conditions.

Task 3: Prepare a cone wedge ring expansion test in a hot cell environment.

Task 4: Initiate standardization of the proposed modified expansion plug testing protocol.

- Initiate a dialogue with other national laboratories or the technical community to form a blind round robin testing group for the proposed new approach and to compare the approach with other conventional approaches for evaluating fuel cladding mechanical properties.

- Communicate with entities in the nuclear industry, such as fuel clad vendors and nuclear utilities, regarding the proposed new approach for evaluating clad tensile properties.

\section{REFERENCES}

1. K.L. Murty, I. Charit, Texture development and anisotropic deformation of zircaloys, Prog. in Nucl. Energy, 48 (2006) 325-359.

2. J.C. Earthman, K.L. Murty, B. V. Tanikella, J. C. Britt, Effects of grain-shape anisotropy and texture on balanced-biaxial creep of Ti and Zr alloys, J. Miner., Metals, \& Mater. Soc., October (1994) 4854.

3. K.L. Murty, B. V. Tanikella, J.C. Earthman, Effect of grain shape and texture on equi-biaxial creep of stress relieved and recrystallized Zircaloy-4, Acta Metal. Mater., 42 (1994) 3653-3661.

4. K.L. Murty, Biaxial creep behavior of textured Zircaloy tubing, J. Metals, February (1992) 49-55. 
5. S.T. Mohmood, K.L. Murty, localized plastic flow, anisotropic mechanical properties and crystallographic texture in Zircaloy sheet, J. Mater. Eng., 11 (1989) 315-329.

6. R.P. Marshall, Influence of fabrication history on stress-oriented hydrides in Zircaloy tubing, J. Nucl. Mater. 24 (1967) 34-48.

7. R. Guillen, C. Cossu, M. Francois, E. Girard, Texture and residual-stresses analysis in Zircaloy-4 cylindrical samples, J. Nucl. Mater., 255 (1998) 174-179.

8. C.B. Cupp, The effect of neutron irradiation on the mechanical properties of Zirconium-2. 5\% niobium alloy, J. Nucl. Mater. 6 (1962) 241-255.

9. E. Tenckhoff, Deformation mechanisms, texture, and anisotropy in zirconium and Zircaloy, ASTM STP 966. American Society for Testing and Materials, Philadelphia, Pa (1988).

10. P. Delobelle, P. Robinet, P. Geyer, P. Bouffioux, A model to describe the anisotropic viscoplastic behavior of Zircaloy-4 tubes, J. Nucl. Mater., 238 (1996) 135-162.

11. D. Ciurchea, Texture induced anisotropy in Zircaloy-4 tubes, J. Nucl. Mater., 131 (1985) 1-10.

12. R.S. Daum, S. Majumdar, H. Tsai, T. S. Bray, D. A. Koss, A. T. Motta, M.C. Billone, Mechanical property testing of irradiated Zircaloy cladding under reactor transient conditions, Small Specimen Test Techniques: Fourth Volume, ASTM STP 1418.

13. J. Desquines, D.A. Koss, A.T. Motta, B. Cazalis, M. Petit, The issue of stress state during mechanical tests to assess cladding performance during a reactivity-initiated accident (RIA), J. Nucl. Mater., 412 (2011) 205-267.

14. A. Hermann, S.K. Yagnik, D. Gavillet, Effect of local hydride accumulations on Zircaloy cladding mechanical properties, Sunriver, OR, United States, American Society for Testing and Materials, 1505 STP (2009)141-162.

15. A.M. Garde, G.P. Smith, R.C. Pirek, Effects of hydride precipitate localization on the ductility of irradiated Zircaloy-4, in: 11th International Symposium on Zr in the Nucl. Industry, GarmischPartenkirchen, Germany, ASTM, STP 1295 (1996) 407-430.

16. L.M. Lowry, A.J. Markworth, J.S. Perrin, M.P. Landow, Evaluating strength and ductility of irradiated Zircaloy-4 Task 5, NRC, Doc.No NUREG/CR-1729, 1981.

17. M. Nakatsuka, M. Aita, K. Sakamoto, T. Higuchi, An open-end burst test method to obtain uniaxial hoop tensile properties, J. Nucl. Mater., 434 (2013) 303-310.

18. M.L. Saux, C. Poussard, X. Averty, S. Carassou, J. Besson, A model to describe the anisotropic viscoplastic mechanical behavior of fresh and irradiated Zircaloy-4 fuel claddings under RIA loading conditions, Transactions, SMiRT 19, Toronto, August 2007, Paper \# C01/4

19. F. Nagase, T. Fuketa, Investigation of hydride rim effect on failure of Zircaloy-4 cladding with tube burst test, J. Nucl. Sci. and Technol., 42 (2005) 58-65.

20. B. Cazalis, J. Desquines, C. Poussard, M. Petit,Y. Monerie, C. Bernaudat, P. Yvon, X. Averty, The Prometra Program: Fuel cladding mechanical behavior under high strain rate, Nucl. Technol., 157 (2007) 215-229.

21. M. Le Sauxa, J. Bessob, S. Carassou, A model to describe the mechanical behavior and the ductile failure of hydrided Zircaloy-4 fuel claddings between $25^{\circ} \mathrm{C}$ and $480^{\circ} \mathrm{C}$, J. Nucl. Mater., 466 (2015) 43-55.

22. M. Le Saux, J. Besson, S. Carassou, C. Poussard, X. Averty, Behavior and failure of uniformly hydrided Zircaloy-4 fuel claddings between $25^{\circ} \mathrm{C}$ and $480^{\circ} \mathrm{C}$ under various stress states, including RIA loading conditions, Eng. Failure Anal., 17 (2010) 683-700.

23. J. Kim , M. Lee , B. Kwon Choi, Y. Jeong, Deformation behavior of Zircaloy-4 cladding under cyclic pressurization, J. Nucl. Sci. and Technol., 44 (2007)1275-1280.

24. V. Macdonalda, D.L. Boulch, A.H. de Menibus, J. Besson, Q. Auzoux, J. Crépin, T.L. Jolu, Fracture of Zircaloy-4 fuel cladding tubes with hydride blisters, Procedia Mater. Sci., 3 (2014 ) 233-238.

25. M. Lee, J. Kim, S. Park, B. Choi, Y. Jeong, The circumferential tensile properties of zirconium alloy fuel claddings under a simulated high burn-up environment, Met. Mater. Int., 15 (2009) 539-546.

26. G. Jeong, Y.Choi, S. Hong, Mechanical performance of oxidized $\mathrm{Zr}-\mathrm{Nb}-\mathrm{O}$ nuclear cladding tubes, The Physics of Metals and Metallography, 115 (2014) 1281-1284. 
27. V. Grigoriev, R. Jakobsson, B. Josefsson, D. Schrire, Advanced techniques for mechanical testing of irradiated cladding materials, IAEA-TECDOC-1277, XA0201401, Proceedings of a Technical Committee Meeting in Dimitrovgrad, Russian Federation, May 2001.

28. S. Kim, J. Bang, D. Kim, Y. Yang, K. Song, D. Kim, Mechanical property evaluation of high burn-up nuclear fuel cladding using the ring tensile test, Met. Mater. Int., 15 (2009) 547-553.

29. J. Desquines, B. Cazalis,C. Bernaudat, C. Poussard, X. Averty, P. Yvon, Mechanical properties of Zircaloy-4 PWR fuel cladding with burnup 54-64MWd/kgU and implications for RIA behavior, J. ASTM International, June 2005, 2, No. 6, Paper ID JAI12465.

30. L. Yegorova, V. Asmolov, G. Abyshov, V. Malofeev, A. Vvakumov, E. Kaplar, K.Lioutov, A. Shestopalov, A. Bortash, L. Maiorov, K. Mikitiouk, V. Povlanov, V.Smirnov, A. Goryachev, V. Prokhorov, V. Pakhnitz, A. Vurim, Data base on the behavior of high burnup fuel rods with Zr-1\%Nb cladding and $\mathrm{UO}_{2}$ fuel (VVER type) under reactivity accident conditions, NRC, Doc. No NUREG / IA/0156 - vol.2, 1999.

31. K.W. Barlow, R. Chandra, Int. J. Fatigue 27 (2005) 1661-1668.

32. J. Calcaterra, Samir Naboulsi, Int. J. Fatigue 27 (2005) 1133-1141.

33. S. Arsène, J. Bai, J. Test. Eval. 26 (1998) 26-30.

34. M. Le Saux, J. Besson, S. Carassou, C. Poussard, X. Averty, J. Nucl. Mater. 378 (2008) 60-69.

35. V. Grigoriev, R. Jakobsson, D. Schrire, Further development of mechanical test to simulate RIA in irradiated cladding, in: 24th NSRR Technical Review Meeting (JAERI-Conf 2001-010), Ibaraki-ken, Japan, JAERI (2001) 139-49.

36. V. Grigoriev, R. Jakobsson, D. Schrire, Temperature effect on BWR cladding failure under mechanically simulated RIA conditions, JAERI, Ibaraki-ken, Japan (2002) 97-106.

37. O. Dufourneaud, A.G. Varias, V. Grigoriev, R. Jakobsson, D. Schrire, Numerical simulation of the expansion-due-to-compression test, JAERI, Ibaraki-ken, Japan (2002) 142-62.

38. T. Sugiyama, High burnup LWR fuel behavior under RIA conditions, Fuel Safety Research Meeting, Kyoto, Japan, October 7, 2005.

39. H. Abe, T. Abe, S. Kishita, S. Kano, Y. Li, H. Yang, K. Tawara, Y. Matsukawa, Y. Satoh, Development of advanced expansion due to compression (A-EDC) test method for safety evaluation of degraded nuclear fuel cladding materials, J. Nucl. Sci. and Technol., 52 (2015) 1232-1239.

40. M.A. Martin-Rengela, F.J. Gomez Sanchez, J. Ruiz-Hervias, L. Caballero, Determination of the hoop fracture properties of unirradiated hydrogen-charged nuclear fuel cladding from ring compression tests, J. Nucl. Mater., 436 (2013) 123-129.

41. J. Ruiz-Hervías, F. J. Gomez, M.A. Martín-Rengel, E. Torres, Structural integrity of hydrided nuclear fuel cladding, Materials Research Society Symposium Proceedings, M23500/1475, 1475 (2012) 151156.

42. F. Nagase, T. Chuto, T. Fuketa, Ring compression ductility of high-burnup fuel cladding after exposure to simulated LOCA conditions, J. Nucl. Sci. and Technol., 48 (2011) 1369-1376.

43. V. Busser, M.-Christine, B.-Dubourg, J. Desquines, C. Duriez, J.-P. Mardon, J. Nucl. Mater. 384 (2009) 87-95.

44. T.M. Link, D.A. Koss, A.T. Motta, Nucl. Eng. Des. 186 (1998) 379-394.

45. S.L. Kampe, D.A. Koss, Acta Metall. 34 (1986) 55-61.

46. R.H. Wagoner, Metall. Mater. Trans. A 11A (1980) 165-175.

47. S. Carassou, M. Le Saux, J.P. Pizzanelli, O. Rabouille, X. Averty, C. Poussard, B.Cazalis, J. Desquines, C. Bernaudat, Ductility and failure behaviour of both unirradiated and irradiated Zircaloy 4 cladding using plane strain tensile specimens, OECD/NEA Workshop on the Behaviour of Nuclear Reactor Fuel during Reactivity Initiated Accidents, Paris, France, 2009.

48. M. Leroy, A. Parrot, S. Leclercq, Failure characteristics of cladding tubes under RIA conditions through electromagnetic forming, SMIRT 19, Toronto, Canada, 2007.

49. S. Leclercq, A. Parrot, M. Leroy, Nucl. Eng. Des. 238 (2008) 2206-2218. 
50. K. Nilsson, O. Martin, C. Chenel-Ramos, J. Mendes, The segmented expanding cone-mandrel test revisited as material characterization and component test for fuel cladding, Nucl. Eng. and Des., 241 (2011) 445-458.

51. H.C. Chu, S.K. Wu, K.F. Chien, R.C. Kuo, Effect of radial hydrides on the axial and hoop mechanical properties of Zircaloy-4 cladding, J. Nucl. Mater. 362 (2007) 93-103.

52. Hendrich et al., Expanded plug method for developing circumferential mechanical properties of tubular materials, US Patent No. US 7140259 B2, Nov. 28, 2006.

53. H. Jiang, J.J. Wang, Methodology for mechanical property testing of fuel cladding using an expanding plug wedge test, J. Nucl. Mater., 446 (2014) 27-37.

54. O. Dufourneaud, A. G. Varias ,V. Grigoriev, R. Jakobsson, D. Schrire, Elastic-plastic deformation of a nuclear fuel cladding specimen under the internal pressure of a polymer pellet, WCCM V Fifth World Congress on Computational Mechanics, July 2002, Vienna, Austria.

55. Q. Jia, L.X. Cai, C. Bao, Strain fatigue behavior of thin-walled tubes of Zr-1Nb and Zr-4 and thin plates of N18 at elevated temperatures, Applied Mechanics and Mater., 69 (2011) 39-44.

56. K.J. Geelhood, C.E. Beyer,W.G. Luscher, PNNL stress/strain correlation for Zircaloy, PNNL-17700, July 2008.

57. http://www.aksteel.com/pdf/markets_products/stainless/ferritic/430_Data_Sheet.pdf.

58. R. Thrash et al., Southwire Company Overhead Conductor Manual, second ed., Southwire Company, Carrolton, Georgia, 2007.

59. R.L. Brockenbrough, B.G. Johnston, USS Steel Design Manual, January 1981, as published in Structural Alloys Handbook 3, 5, 1994.

60. J.J. Wang, H. Jiang, Development of Cone Wedge Ring Expansion Test to Evaluate Mechanical Properties of Clad Tubing Structure, ORNL/TM-2016/279, September 2016. 